\title{
The Convolvulaceae of Timor with special reference to East Timor
}

\author{
A.R. Simões ${ }^{1,2}, H$. Silva ${ }^{1,3}$, P. Silveira ${ }^{1,3}$
}

Key words

Argyreia

checklist

conservation

ethnobotany

Ipomoea

Merremia

new species

taxonomy

\begin{abstract}
A taxonomic review of the Convolvulaceae in Timor is presented. A total of 61 taxa are listed, comprising 53 species from 15 genera. The most diverse genus by far is Ipomoea with 25 reported species, followed by Merremia with seven species. Of the seven species initially thought to be endemic, only six are endemic to the island. Two new records are presented (Cuscuta campestris and Merremia quinata) and a new species, Argyreia paivae, is described and illustrated. Keys to genera and species are included, as well as distribution maps. The conservation of East-Timorese Convolvulaceae is analysed and it is shown that they are inadequately represented in the established natural reserves' network.
\end{abstract}

Published on 8 April 2011

\section{INTRODUCTION}

East Timor is a recently recognized independent country located in the eastern part of the island of Timor, in the Lesser Sunda Islands group (Bali, Lombok, Sumbawa, Flores, Sumba and Timor). East Timor's potential in natural resources has long been recognised and throughout the centuries, European and Asian traders were attracted to the territory for the commerce of coffee, cacao, tobacco and cotton, and mostly for the exploration of luxury and high profitable products of sandal (Santalum album L.) (Silva 1910, Magro 1943, Wright 2001). The high demand for these products, coupled with poor management of resources and, more recently, destruction caused by conflict, have resulted in the impoverishment of the plant resources of East Timor.

To support the sustainable management of the resources of East Timor, the University of Aveiro, in cooperation with the National University of East Timor, organized a project: 'Contribution to flora resources management in East Timor', to document the flora, identify taxa requiring protection and identify taxa that have the potential for sustainable use. Botanical expeditions conducted in 2004 and 2005 resulted in 750 specimens collected in nine different districts of the country (deposited in AVE). The Orchidaceae has already been studied with the contribution of these data (Silveira et al. 2008) and the results included 15 new genera and 32 new species records for the island. Ten species were found to be endemic and four new species were described. The conservation status of 12 species was assessed, of which eight were considered to be Critically Endangered and three others Endangered.

The Convolvulaceae, with seven endemic species (Monk et al. 1997), is the second richest family in terms of endemism for Timor, after Orchidaceae. Species of Convolvulaceae are

\footnotetext{
${ }^{1}$ Departamento de Biologia, Universidade de Aveiro, Campus Universitário de Santiago, 3810-193 Aveiro, Portugal;

e-mail: ana.simoes@nhm.ac.uk, hsilva@ua.pt, psilveira@ua.pt.

2 Present address: Department of Botany, The Natural History Museum of London, Cromwell Road, SW7 5BD London, United Kingdom.

${ }^{3}$ CESAM, Universidade de Aveiro, Campus Universitário de Santiago, 3810193 Aveiro, Portugal.
}

also economically important (Van Ooststroom \& Hoogland 1953). Many species are used as edible crops, ornamentals or medicinal plants and some are serious weeds. Although controversially placed in this family Cuscuta is a significant parasite of crop plants (Heywood et al. 2007).

The most complete taxonomic account of the Convolvulaceae from Timor was provided by Van Ooststroom (Van Ooststroom \& Hoogland 1953). However, there have been additions and emendations to this publication and many recently published works have brought new perspectives on the taxonomy of the family. Also, new collections in West and East Timor, have documented new local records of some taxa.

The purpose of this study was therefore to produce an up-todate checklist and identification keys to the Convolvulaceae of Timor. Due to the paucity of specimens available, and the old age of many of them, it was not possible to assess accurately the conservation status of taxa. However, as a contribution to future studies on this topic, distribution maps and notes on habitat and ecology of the species are provided.

\section{MATERIAL AND METHODS}

Whilst this checklist is focused on the territory of East Timor, collections and species from West Timor (Indonesia) were also included because there are no significant ecological differences between the two areas and some older specimens are only labelled 'Timor'.

The study was based on herbarium specimens from Timor (both East and West) held in the following herbaria: AVE, BM, COI, G, L, LISC, K and P, together with specimens collected in two botanical expeditions to the eastern part of the island only (2004 and 2005), and bibliographic sources. Overall, 283 specimens were studied and a variety of literature consulted, including several Asian Floras, taxonomic revisions of the genera and species and governmental publications regarding the administration of the natural resources of East Timor

The checklist provides details of basionyms, synonyms cited for Timor and reference to types, where these were collected in Timor. 
Information on distribution, habitat and ecology, vernacular names and traditional uses are provided. The latter is based on ethnobotanical information from across the distribution range of the taxa, not only Timor, so as to demonstrate potential uses that are not known in the island but that could be further investigated (e.g. pharmaceutical research) in favour of the country's development.

The original orthography of collection sites was generally respected although in some cases it was subject to our interpretation. When in doubt, a question mark follows the name, between parentheses.

Identification keys are provided for genera, species and infraspecific taxa. Previously, the only available key was from Flora Malesiana, which covers Convolvulaceae from the whole Malesian region and is unnecessarily complex for an island as small as Timor. The keys are restricted to the characters of the taxa known to occur in the island and an attempt was made to give priority to characters that would be present in vegetative specimens, although this could not always be achieved.

For the study of the species of Argyreia in Timor, morphological observations were made on herbarium specimens of $A$. paivae A.R.Simões \& P.Silveira, A. reinwardtiana (Blume) Miq. and A. walshae Ooststr. from BM, K, L and LISC. Pollen samples were taken from one individual each of all three species, and were subjected to acetolysis according to the method of Erdtman (1960) after which pollen grain morphology and ornamentation were observed using light microscopy (LM) and scanning electron microscopy (SEM). For LM the pollen samples were pre-treated with t-butanol, mounted in silicon oil (Andersen 1960), and observed using a Olympus CX31 light microscope. For SEM the samples were dehydrated in ethanol and pollen grains were mounted on aluminium stubs and coated under high vacuum with a gold/palladium film using a Jeol JFC-1100 Ion Sputter. Pollen samples were then observed with a HITACHI S-4100 SEM operating at $25 \mathrm{kV}$. LM slide preparations and SEM stub preparations are held at AVE.

\section{TAXONOMIC TREATMENT}

\section{Key to the genera of Convolvulaceae}

1. Parasites, lacking chlorophyll, leafless or with minute, scalelike leaves ... . . . . . . . . . . . . . . 3. Cuscuta

1. Non-parasitic plants, with green leaves . . . . . . . . 2

2. Style absent, stigma conical with 10 distinct ridges..... . . . . . . . . . . . . . . . . . . . . 5. Erycibe

2. Style(s) present, stigma(s) otherwise $\ldots \ldots \ldots \ldots \ldots 3$

3. Styles $2 \ldots \ldots \ldots \ldots \ldots \ldots \ldots \ldots \ldots \ldots \ldots$

3. Style $1 \ldots \ldots \ldots \ldots \ldots \ldots \ldots \ldots \ldots \ldots \ldots \ldots \ldots \ldots \ldots \ldots$

4. Styles forked. Stigmas filiform or slightly clavate. Corolla-limb nearly entire . . . . . . . . . . . . . 6volvulus

4. Styles not forked. Stigmas capitate. Corolla-limb distinctly lobed . . . . . . . . . . . . . . . . . 2. Cressa

5. Flowers in racemose, paniculate or thyrsiform inflorescences

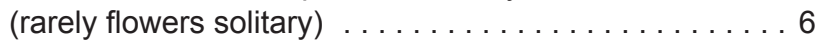

5. Flowers in one- to few- or many-flowered axillary cymose inflorescences $\ldots \ldots \ldots \ldots \ldots \ldots \ldots \ldots \ldots \ldots \ldots \ldots$

6. Leaf venation pedate, veins prominent, often alate abaxially. Calyx covering $1 / 4$ or less of corolla tube. Stem terete, smooth or striate . . . . . . . . . . . . . . Dinetus

6. Leaf venation pinnate, veins not prominent and not alate abaxially. Calyx covering half or more of the corolla tube. Stem lenticellate ............... 13. Porana

7. Stigmas $4 \ldots \ldots \ldots \ldots \ldots \ldots \ldots \ldots$ 12. Polymeria

7. Stigmas $2 \ldots \ldots \ldots \ldots \ldots \ldots \ldots \ldots$
8. Stigmas tongue-shaped. . . . . . . . . . 9. Jacquemontia

8. Stigmas not tongue-shaped. . . . . . . . . . . 9

9. Stigmas ovate-oblong, complanate ... . . . 7. Hewittia

9. Stigmas biglobose . . . . . . . . . . . . . . 10

10. Pollen echinate $\ldots \ldots \ldots \ldots \ldots \ldots \ldots \ldots \ldots \ldots \ldots$

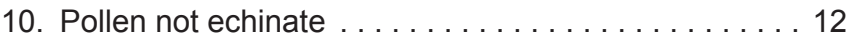

11. Leaf-blades with black dots beneath. Calyx completely enclosing the ripe fruit. Fruit with distinct exocarp and endocarp; the endocarp with two well-developed ridges

14. Stictocardia

11. Leaf-blades without black dots beneath. Calyx not completely enclosing the ripe fruit. Fruit without distinct endo-

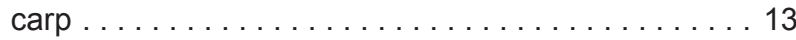

12. Fruit a capsule opening by a more or less fleshy circumscissile lid (operculum) on the upper part of the epicarp. Stems terete or winged . . . . . . . . . .11. Operculina

12. Fruit a capsule opening by four valves. Stems terete or striate, but never winged . . . . . . . . . . . 14

13. Fruit a thin-walled capsule opening by valves or irregularly dehiscing . . . . . . . . . . . . . . 8 . . . . .

13. Fruit indehiscent, a flesh, leathery berry ... . 1. Argyreia

14. Pollen pantoporate. Leaves linear (in some cases nearly filiform), linear-oblong to oblanceolate, spathulate or subquadrate; base truncate to hastate; basal lobes obscurely to sharply dentate . . . . . . . . . . . . . 15. Xenostegia

14. Pollen 3-12-colpate or 12-rugate. Leaves of various shapes, not as above . . . . . . . . . . . . . 10. . . .

\section{ARGYREIA Lour. (1790) 134}

\section{Key to the species of Argyreia}

1. Sepals unequal, two outer ones (10-)15-18 mm long, two inner ones (7-)8-9 $\mathrm{mm}$; the outer ones with more or less undulate margins. Corolla funnel-shaped, purplish pink, $3-4.5 \mathrm{~cm}$ long . . . . . . . . . . . 2. A. reinwardtiana

1. Sepals subequal, $5-8 \mathrm{~mm}$ long; margins entire. Corolla tubular to funnel-shaped, whitish or yellowish, $2-3 \mathrm{~cm}$ long . 2

2. Leaves broadly ovate to ovate; length less than two times the width. Lower surface densely pubescent to tomentose with short curled hairs ............. 3. A. walshae

2. Leaves narrowly ovate; length two or more times the width. Lower surface sparsely to rather densely pilose with short appressed, straight hairs ............ A. paivae

\section{Argyreia paivae A.R.Simões \& P.Silveira, sp. nov. - Fig. 1, 2; Map 1}

Ab Argyreia walshae Ooststr. foliis multo longioribus anguste ovatus (nec late ovatis vel ovatis) et subtus pilis brevibus adpressis rectis (nec crispatis) instructis differt. - Typus: Friedberg 257a (holo LISC), East Timor, Abis, 1.vi.1966.

Etymology. The name Argyreia paivae is a tribute to Jorge Paiva, who has dedicated his life to the study of tropical flora and who gave a fundamental contribution to this project.

Woody twiner. Stems with milky sap, sparsely pilose with short, appressed whitish hairs when young, later glabrescent and lenticellate. Leaves narrowly ovate, two or more times as long as wide, $6.5-12 \mathrm{~cm}$ long, $2-5 \mathrm{~cm}$ broad, rounded at the base, attenuate to acuminate at the apex, glabrous or nearly so above, sparsely to rather densely pilose beneath with short, appressed, straight hairs; midrib and $10-13$ pairs of lateral nerves rather prominent beneath; petiole $2-5 \mathrm{~cm}$ long, appressed-pilose. Inflorescences axillary; 3-10-flowered compound cymes; peduncles shorter or as long as the petiole, 
b
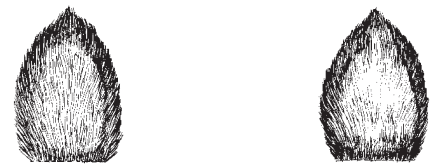

C

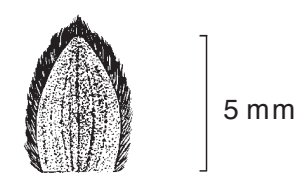

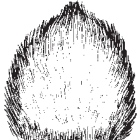
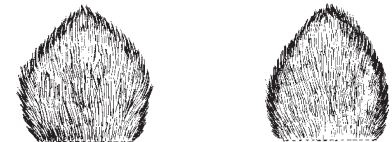

$5 \mathrm{~mm}$

d

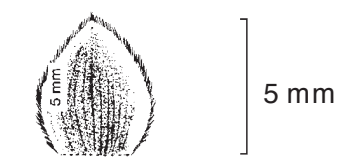

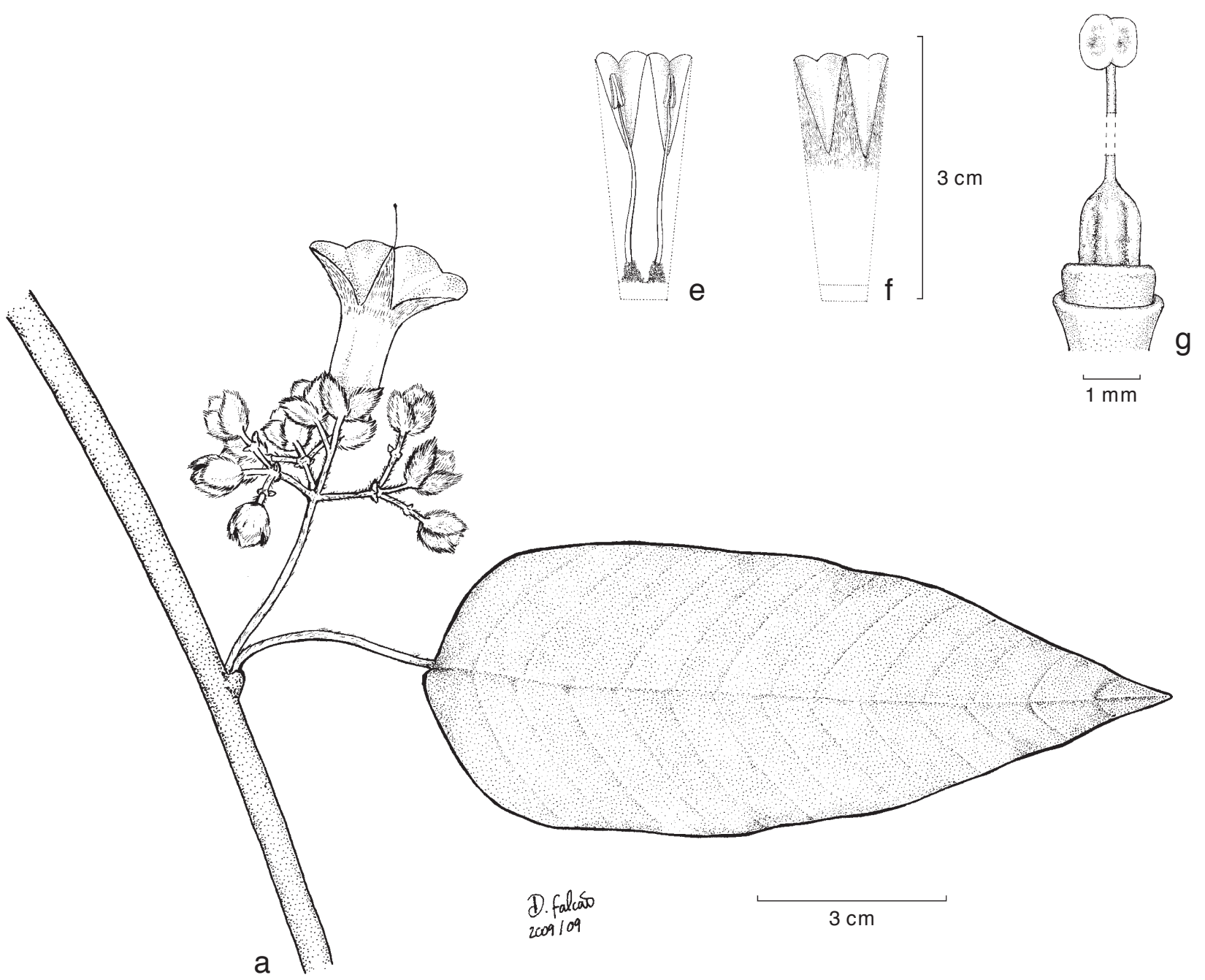

Fig. 1 Argyreia paivae A.R.Simões \& P.Silveira. a. Node with inflorescence and leaf; b. corolla section, view from inside; c. corolla section, view from outside; d. ovary and disk; e. sepals, view from outside; two on the left inner ones, three on the right outer ones; f. sepals, view from inside; left hand one of the outer sepals, right hand one of the inner sepals (based on Friedberg 257a, LISC, complemented with information from Kooy 706 and Kooy 905 , both L).

2-5 cm long, densely appressed-pilose. Bracts oblong, 2-3 mm long, appressed-pilose outside, glabrous inside, caducous. Pedicels 3-6 mm, hairy like the peduncles, thickened towards the apex. Sepals subequal, the outer two ovate, the inner three broadly ovate, 5-6 $\mathrm{mm}$ long, apices obtuse, outside fulvous tomentose, inside glabrous and brown, three inner ones with a slightly scarious margin. Corolla whitish, tubular to funnelshaped, c. 2-3 cm long, the limb shallowly lobed, midpetaline bands and upper portion of the tube sericeous. Stamens slightly exserted; filaments c. $20 \mathrm{~mm}$ long, inserted at c. $5 \mathrm{~mm}$ from the base of the corolla tube, hairy at the base; anthers sagitate, c. $3 \mathrm{~mm}$ long. Disc annular, c. $0.5 \mathrm{~mm}$ high. Ovary, 2-celled, glabrous; style glabrous, exserted, 20-25 mm long, stigma globose. Fruit unknown.
Distribution - Timor.

Habitat \& Ecology - Thick liana, growing over shrubs, collected at $700 \mathrm{~m}$.

Uses - The bark can be boiled and the resulting water is drunk for treating gonorrhoea.

Vernacular name - Mau halé (Timor: unknown dialect).

Other specimens examined. INDONESIA, West Timor, Nikiniki, 700 m, 1.iv.1974, Kooy 905 (L!); Supul, c. 750 m, 25.iii.1969, Kooy 706 (L!).

Notes - We examined specimens of Argyreia from Timor and three of them stood out because they did not appear to match any of the species of Argyreia included in Flora Malesiana (Van Ooststroom \& Hoogland 1953). After careful study, extensive comparison with the descriptions of species from 


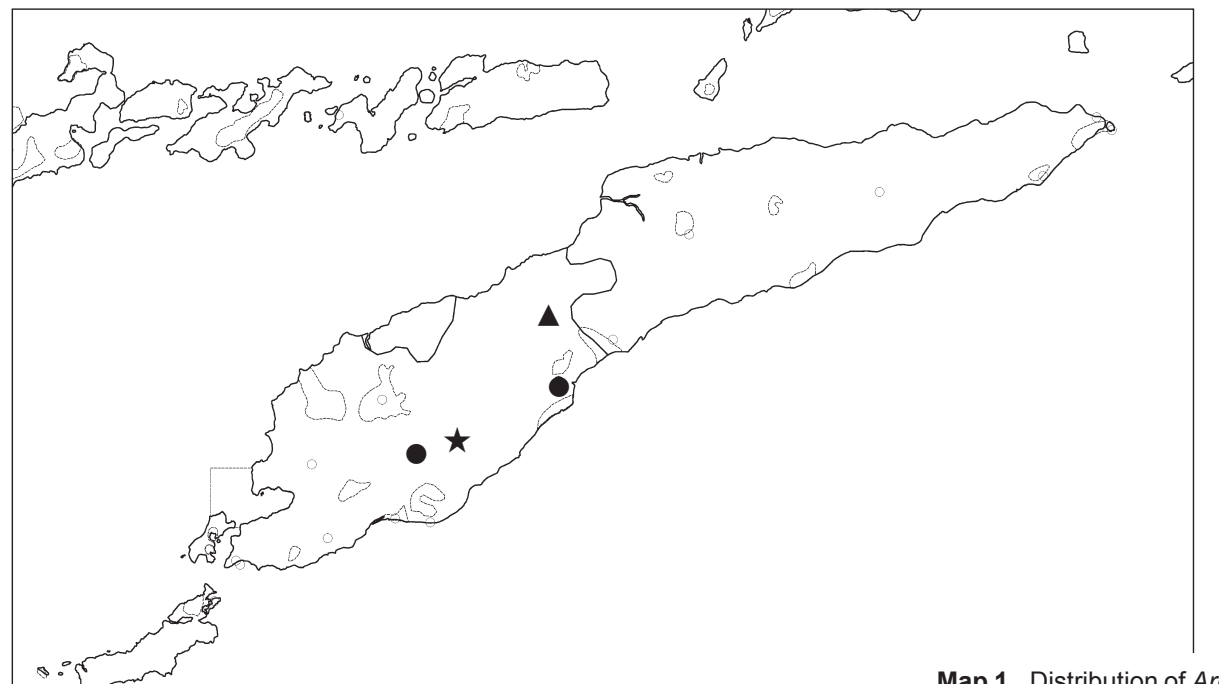

Map 1 Distribution of Argyreia paivae A.R.Simões \& P.Silveira ( $\star$ ) , A. reinwardtiana (Blume) Miq. (@) and A. walshae Ooststr. (A).

other territories and comparison with herbarium material (especially from $B M, K$ and $L$ ), it was found necessary to describe $A$. paivae as a new species.

Specimens of $A$. paivae share some characteristics with each of the other two Timorese endemic species: A. reinwardtiana and $A$. walshae. Like $A$. reinwardtiana this new species has the lower leaf surfaces sparsely to rather densely pilose with short, appressed, straight hairs, while in $A$. walshae the lower surface is densely pubescent to tomentose with short curled hairs. The inner and outer sepals are subequal and thus similar to those of A. walshae. In A. reinwardtiana, the outer sepals are distinctly larger than the inner ones, with peculiar undulate margins. The indumentum of the sepals is also like that of $A$. walshae, in that it is entirely densely sericeous outside. In A. reinwardtiana, the sepals are distinctly less sericeous towards the apex. A distinctive feature of $A$. paivae are the narrowly ovate leaves that are at least twice as long as they are wide. The other two Timor endemics have broadly ovate to ovate leaves, the length of which is less than two times the width. Given the distinctive leaf shape of $A$. paivae, the possibility that it is a hybrid between the two other Timorese species is unlikely.

In the absence of fruit, and in order to confirm that these specimens should indeed be included in the genus Argyreia, we studied the pollen morphology of the three endemic Timor Argyreia (Fig. 2).

The pollen of all three species is very similar, apolar, with radial symmetry, circular in optical section, pantoporate. In detail, they are characterised in the following way: diameter 83-100 $\mu \mathrm{m}$; pori operculate, diameter of opercula $6-8 \mu \mathrm{m}$; opercula microreticulate-cristate; exine c. $16 \mu \mathrm{m}$ thick under the spines, c. $9 \mu \mathrm{m}$ between the spines; tectum echinate-microreticulate-cristate; spines 6.8-9.4 $\mu \mathrm{m}$ long (excluding the dilated exine bases), cylindrical, obtuse, psilate, with subglobose, microreticulatecristate bases.

Considering that the fruit of $A$. reinwardtiana is known (Van Ooststroom \& Hoogland 1953) and that the pollen morphology is very similar in all three species, we can confirm that the complex belongs to Argyreia.

\section{Argyreia reinwardtiana (Blume) Miq. - Fig. 2; Map 1}

Argyreia reinwardtiana (Blume) Miq. (1857) 589. - Type: Reinwardt 1351 (holo L), Timor.

Ipomoea reinwardtiana Blume (1826) 720

Argyreia guichenotii Choisy (1834) 423; Decne. (1834) 388; Span. (1841) 338; Miq. (1856) 589; Fawc. (1885) 511
Distribution - Timor (Van Ooststroom \& Hoogland 1953).

Habitat \& Ecology - Creeper; found between chalkrocks; collected at 200 and c. $762 \mathrm{~m}$.

\section{Argyreia walshae Ooststr. - Fig. 2; Map 1}

Argyreia walshae Ooststr. (1943) 361; Ooststr. (in Ooststr. \& Hoogland 1953) 499; Kalkman (1955) 216. - Type: Walsh 388 (holo L; iso BM), Indonesia (West Timor), Tobaki, c. 800 m, 10.vi.1929.

Distribution - Timor (Van Ooststroom \& Hoogland 1953). Habitat \& Ecology - Not common; collected at c. 800 m.

Note - Van Ooststroom (Van Ooststroom \& Hoogland 1953) makes a note that this species is rather frequent in Timor. However, Mrs. Walsh's collection notes on the type indicate the opposite.

\section{Doubtful records}

Argyreia setosa Choisy (1834) 425; Decne. (1834) 388; Span. (1841) 338; Miq. (1856) 592

Miquel (1856) quotes Spanoghe (1841), who assumes the presence of this species in Timor based on Decaisne's publication (1834). Still, Decaisne did not show evidence of this, instead stating: "Je n'ai point vu dans les herbiers du Muséum cette espèce originaire de Timor, je la cites d'après l'autorité de M. Choisy".

Choisy (1834) clearly assumed the presence of such species in Timor but no specimens have been found to support such statement. Van Ooststroom (Van Ooststroom \& Hoogland 1953) has suggested that the specimen mentioned by Choisy might belong to $A$. reinwardtiana.

\section{Argyreia capitiformis (Poir.) Ooststr. (1972) 941}

Ipomoea trichotosa Blume (1826) 717; Span. (1841) 340 Argyreia capitata (Vahl) Choisy (1834) 423; Miq. (1856) 589.

This species has been listed as occurring in Timor, but no specimens have been found to support this statement.

2. CRESSA L. (1753) 223

1. Cressa australis R.Br. - Map 2

Cressa australis R.Br. (1810) 490

Cressa cretica auct. non L. (1753) 223; Ooststr. (1972) 937. 

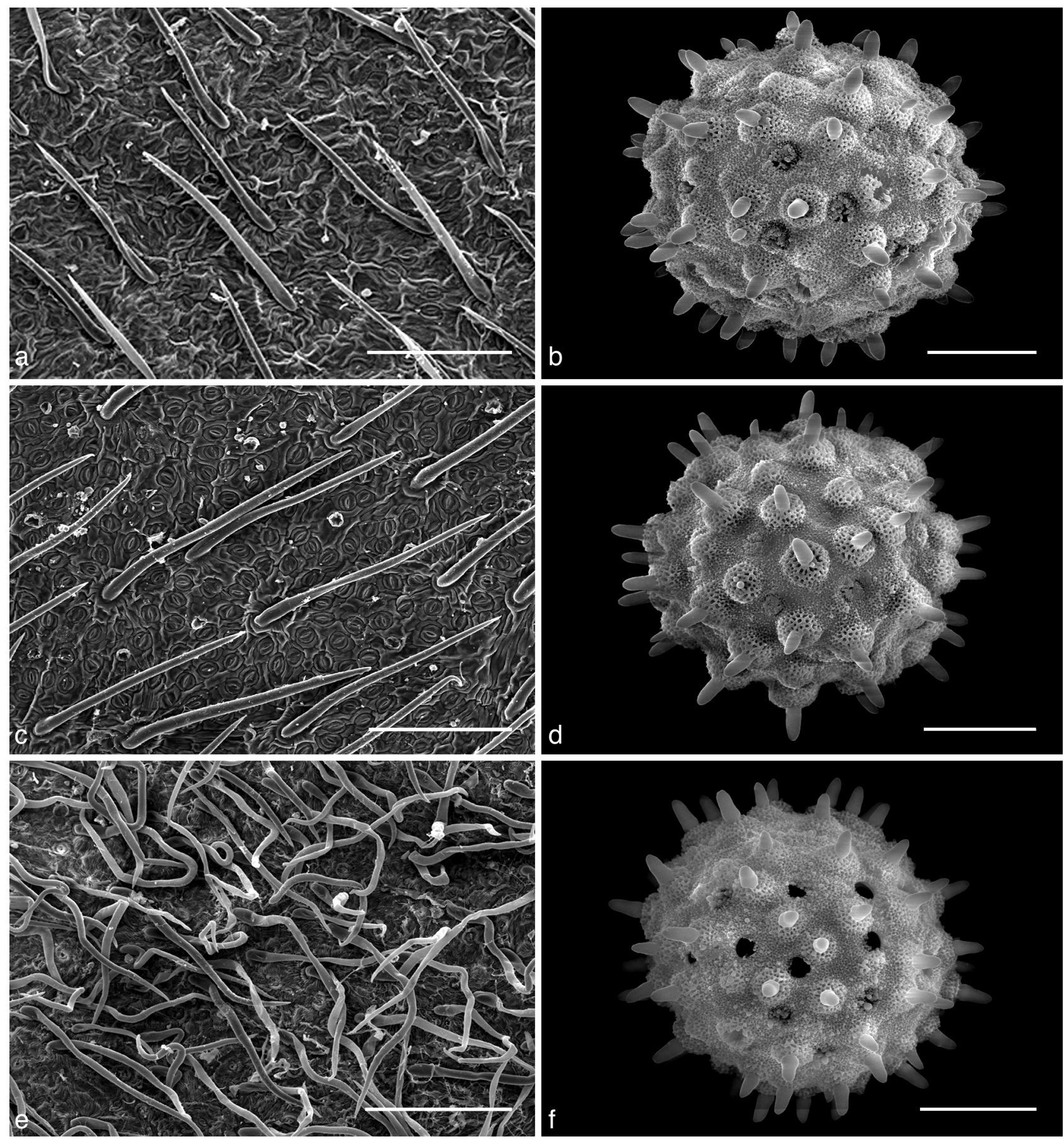

Fig. 2 SEM images showing detail of indumentum of abaxial surface of the leaf (left) and pollen morphology (right) of all three species of Argyreia from Timor. a, b. Argyreia paivae A.R.Simões \& P.Silveira; c, d. Argyreia reinwardtiana (Blume) Miq.; e, f. Argyreia walshae Ooststr.

Distribution - East Timor, Australia (Western Australia, Northern Territory, Southern Australia, Queensland, New South Wales, Victoria) (Austin 2000).

Habitat \& Ecology - The only specimen known from Timor was collected at $100 \mathrm{~m}$ from the sea in a pure stand in the shade of the mangrove tree Avicennia marina.

Note - Van Ooststroom (1972) recognised the specimen from Timor as the only known occurrence of this genus in Malesia. Although he noted several differences between Australasian and European material, he was unable to recognise specific differences and consequently treated the Timor material as Cressa cretica. Austin (2000) studied the morphological variation in the genus and came to conclude that the specimen from Timor would be better placed in Cressa australis.

\section{CUSCUTA L. (1753) 124}

\section{Key to the species of Cuscuta}

1. Stems filiform, less than $0.5 \mathrm{~mm}$ wide. Styles 2 , distinct. Ovary depressed-globose .......... 1. C. campestris

1. Stems $0.5-2 \mathrm{~mm}$ or more diam. Style 1 , longer than the depressed-globose stigmas. Ovary ovoid-conical . .

2. C. cassytoides

\section{Cuscuta campestris Yunck. - Map 3}

Cuscuta campestris Yunck. (1932) 138.

Distribution - Native of North America, recently introduced in several countries of the Old World (Liao et al. 2005). New record for Timor. 


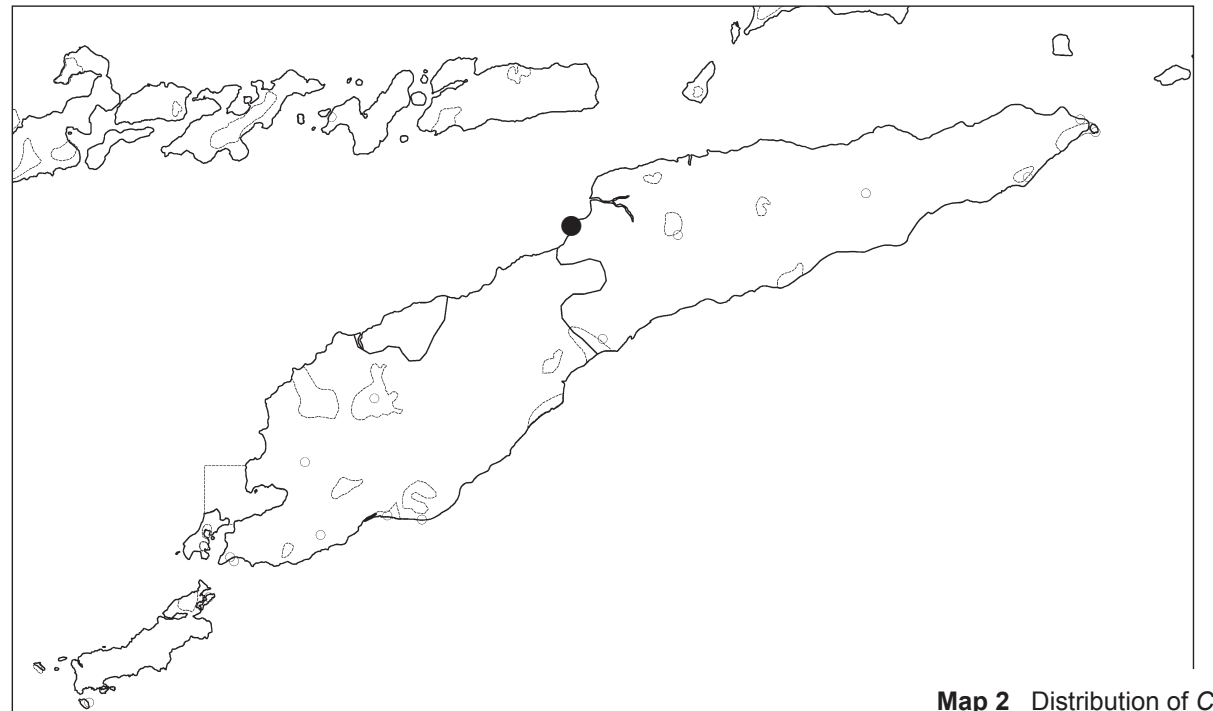

Map 2 Distribution of Cressa australis R.Br.

Habitat \& Ecology - Often on Medicago sativa, Trifolium and Satureja hortensis, but also on a great number of other herbaceous plants (Van Ooststroom \& Hoogland 1953).

\section{Cuscuta cassytoides Nees ex Engelm. - Map 3}

Cuscuta cassytoides Nees ex Engelm. (1859) 513; Ooststr. (1958) 558. Cuscuta timorensis Decne. ex Engelm. (1859) 514; Ooststr. (in Ooststr. \& Hoogland 1953) 393; Kalkman (1955) 216.

Cuscuta monogyna auct. non Vahl (1791) 32; Miq. (1856) 632; Fawc. (1885) 511.

Cuscuta reflexa auct. non Roxb. (1799) 3, t. 104; Decne. (1834) 393; Span. (1841) 341; Fawc. (1885) 511

Distribution - East Africa to South Africa and South Malesia: East Java (Asem Bagus) and Lesser Sunda Islands (Timor, Wetar) (Van Ooststroom \& Hoogland 1953).

Habitat \& Ecology — On Ficus glomerata Roxb. and other woody plants; apparently confined to regions with a very dry season (Van Ooststroom \& Hoogland 1953). A specimen from Timor was found at $300 \mathrm{~m}$.

Vernacular name - Non-atois (Dawan).

\section{Unidentified specimens}

A specimen, Kooy 903 (L!), remains to be identified at species level. It lacks flowers, presenting only capsules, which do not seem to match the description of any of the above listed species of Cuscuta.
4. DINETUS Buch.-Ham. ex Sweet (1825) t. 127

1. Dinetus racemosus (Roxb.) Buch.-Ham. ex Sweet Map 4

Dinetus racemosus (Roxb.) Buch.-Ham. ex Sweet (1825) t. 127. Porana racemosa Roxb. (1824) 466; Fawc. (1885) 511; Ooststr. (in Ooststr. \& Hoogland 1953) 403; Kalkman (1955) 216

Distribution - Pakistan throughout North India, Nepal, Bhutan, China, Myanmar and Southeast Asia to Malesia (Staples 2006).

Habitat \& Ecology — In open sites in forests, thickets, scrub, on hillsides and along watercourses on diverse soil types at (50-)1 000-2 000(-3 200) m elevation (Staples 2006).

Uses - In China the whole plant is used for treating 'wind damage' and dyspepsia; in Laos the young leaves are eaten with pepper, being edible both in fresh and dry state (Staples 2006).

\section{ERYCIBE Roxb. (1802) 31, t. 159}

\section{Erycibe timorensis Hallier f. ex Hoogl.}

Erycibe timorensis Hallier f. ex Hoogl. (1953) 318; Ooststr. (in Ooststr. \& Hoogland 1953) 423. - Type: Spanoghe 43 (holo L; iso P), Timor.

Distribution - Timor (Van Ooststroom \& Hoogland 1953).

Habitat \& Ecology — In the mountains (Van Ooststroom \& Hoogland 1953).

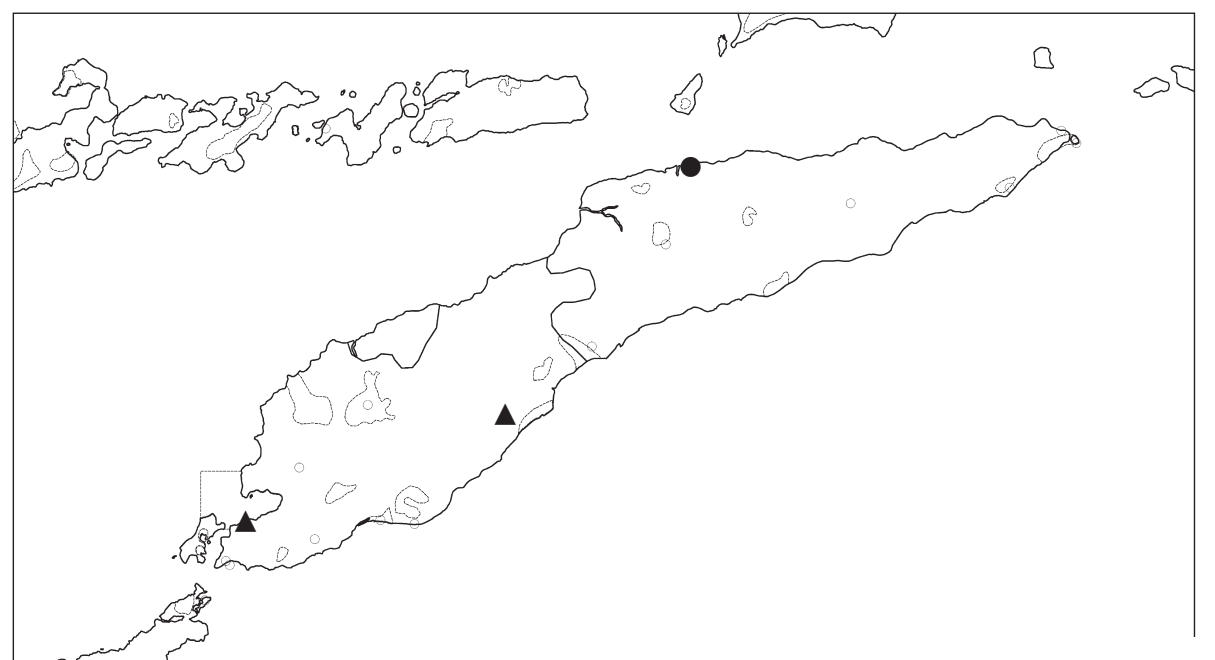

Map 3 Distribution of Cuscuta campestris Yunck. (0) and C. cassytoides Nees ex Engelm. (A). 


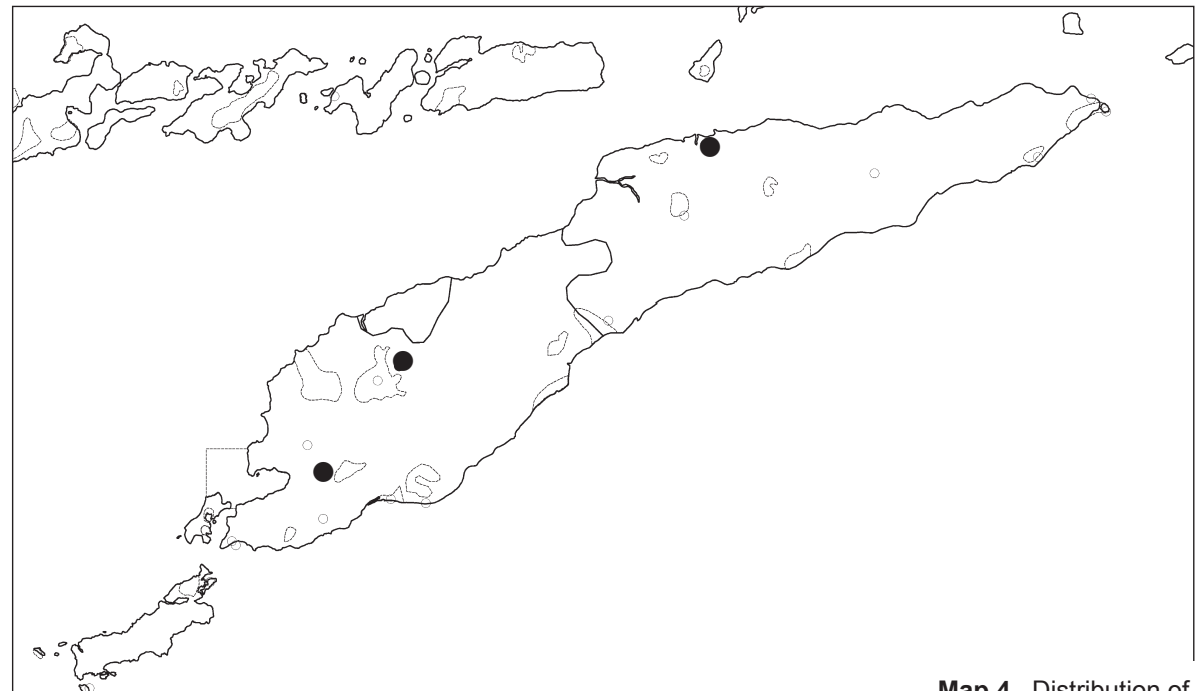

Map 4 Distribution of Dinetus racemosus (Roxb.) Buch.-Ham ex Sweet.

Note - The specimens examined lack precise locality information. Spanoghe is known to have collected in several different localities in Timor but it is not clear where he collected each of the plants. Zippelius, who collected some other specimens of this species, is known to have collected in Kupang and surrounding areas.

\section{EVOLVULUS L. (1762) 391}

Note - Van Ooststroom (1934) has recognised 15 different varieties of Evolvulus alsinoides, the boundaries of which are far from clear-cut. The three varieties existing in Timor are not always easy to separate, and some transitional forms seem to occur, as Van Ooststroom himself observed (Van Ooststroom \& Hoogland 1953).

\section{Key to the varieties of Evolvulus alsinoides}

1. Leaves oblong, elliptic or spathulate, c. 1.5-2.5 times as long as broad, apex obtuse or shallowly emarginate and mucronulate............... a. var. alsinoides

1. Leaves lanceolate to linear, 2.5 or more times as long as broad, apex acute or acuminate . . . . . . . . 2

2. Stems $6-20 \mathrm{~cm}$, rather stiff, densely appressed-pilose with more or less shining hairs. Peduncles shorter than the leaves, 2-5 mm. Sepals appressed-pilose ..... c. var. javanicus
2. Stem $30-45 \mathrm{~cm}$, slender, appressed pilose and patentlypilose, with few or many hairs, not shining. Peduncles longer than the leaves, $15-30 \mathrm{~mm}$. Sepals villose. . . . . . . . . $\ldots \ldots \ldots \ldots \ldots \ldots \ldots$ b. var. decumbens

a. var. alsinoides (L.) L. - Map 5

Evolvulus alsinoides var. alsinoides (L.) L. (1762) 392; Fawc. (1885) 511; Ooststr. (in Ooststr. \& Hoogland 1953) 395; Kalkman (1955) 216.

Convolvulus alsinoides L. (1753) 157.

Evolvulus pumilus Span. (1835) 348; (1841) 341.

Evolvulus pseudo-incanus Span. (1841) 341, nom. nud.

Distribution - Tropical East Africa, Madagascar, India, IndoChina, South China, in Malaysia: Lesser Sunda Islands (Timor), Philippines (Luzon) (Van Ooststroom \& Hoogland 1953).

Habitat \& Ecology - The Malesian varieties of the species can be found in dry grasslands, often on limestone, at low and medium altitudes (Van Ooststroom \& Hoogland 1953). Specimens from Timor have been found on chalk rocks in full sunshine, at 500 and c. $762 \mathrm{~m}$.

Uses - Used in Ayurvedic medicine (Indian subcontinent) as a medicine for a series of mental problems, such as epilepsy, insanity, nervous debility, and loss of memory (Allimuth \& Venilla, Anis et al., Auddy et al., all cited in Austin 2008). Also known to be used as a febrifuge and tonic (Van Ooststroom 1934), and in treating internal haemorrhages or intermittent fever of children (Watt in Van Ooststroom 1934).

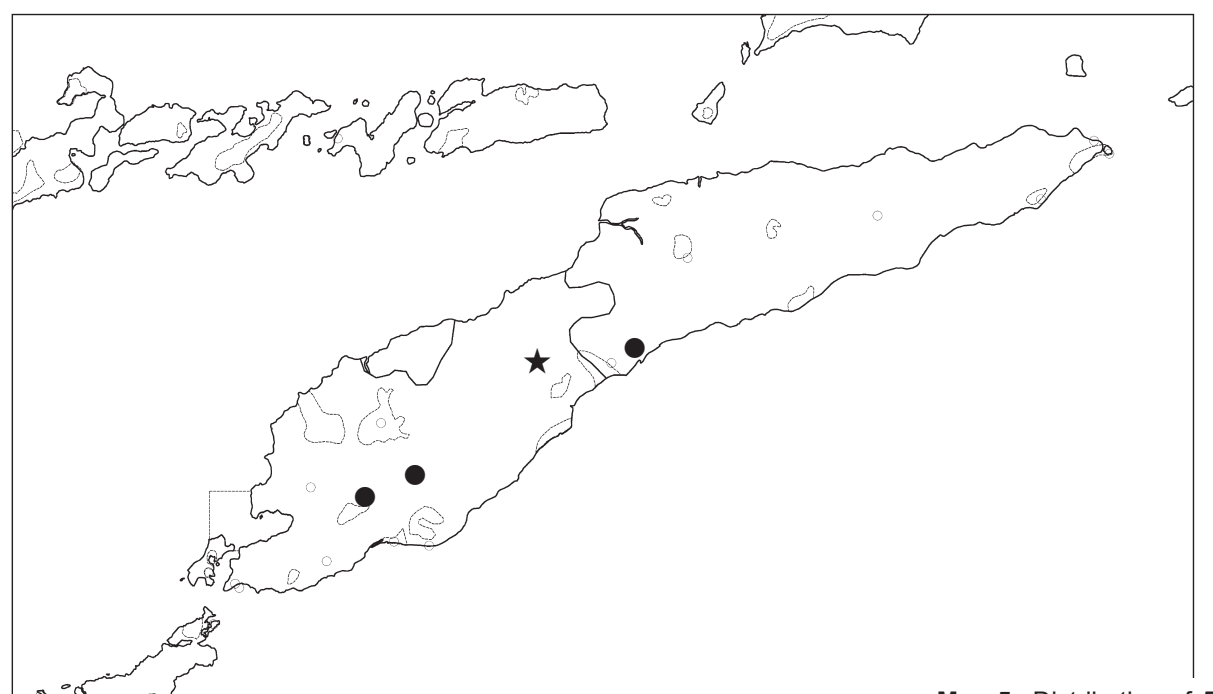

Map 5 Distribution of Evolvulus alsinoides var. alsinoides (L.) L. (๑) and E. alsinoides var. decumbens (R.Br.) Ooststr. ( $\star$ ). 
b. var. decumbens (R.Br.) Ooststr. - Map 5

Evolvulus alsinoides var. decumbens (R.Br.) Ooststr. (1934) 38; Fawc. (1885)

511; Ooststr. (in Ooststr. \& Hoogland 1953) 396.

Evolvulus decumbens R.Br. (1810) 489

Evolvulus lanceaefolius Span. (1841) 341

Distribution - South China and Indo-China to Australia and the Pacific Islands, in Malesia: North Sumatra, Peninsular Malaysia, Lesser Sunda Islands (Bali, Timor, Wetar), Southwest-Southeast Celebes, Moluccas, Philippines (Luzon, Mindanao), New-Guinea (Van Ooststroom \& Hoogland 1953).

Habitat \& Ecology - A specimen from Timor was found at $300 \mathrm{~m}$.

\section{c. var. javanicus (Blume) Ooststr}

Evolvulus alsinoides var. javanicus (Blume) Ooststr. (1934) 39; Ooststr. (in Ooststr. \& Hoogland 1953) 398.

Evolvulus javanicus Blume (1826) 724.

Distribution - Malesia: Lesser Sunda Islands (Timor, Wetar), Moluccas (Van Ooststroom \& Hoogland 1953).

\section{Doubtful record}

Evolvulus linifolius L. (1762) 392; Miq. (1856) 628

Miquel (1856) reports this species for Timor, indicating E. javanicus Blume as a synonym. According to Van Ooststroom (1934) Evolvulus linifolius L. (syn. Evolulus alsinoides var. linifolius (L.) Baker) occurs mainly in Africa, Madagascar and Yemen, and not in Asia. No specimens from Timor were found that could agree with Miquel, and given the difficulty of separating the varieties of Evolvulus alsinoides, it could be that this was a case of confusion between var. linifolius and var. javanicus.

\section{HEWITTIA Wight \& Arn. (1837) 22}

\section{Hewittia malabarica (L.) Suresh - Map 6}

Hewittia malabarica (L.) Suresh in Nicolson, Suresh \& Manilal (1988) 88. Convolvulus malabaricus L. (1753) 155.

Convolvulus sublobatus L.f. (1781) 135

Shutereia bicolor Choisy (1834) 486; Decne. (1834) 392; Span. (1841) 338

Hewittia bicolor (Choisy) Wight. \& Arn. (1837) 22; Fawc. (1885) 511

Convolvulus scandens Delile (1847) 7.

Hewittia sublobata (L.f.) Kuntze (1891) 441; Ooststr. (in Ooststr. \& Hoogland 1953) 438; Kalkman (1955) 216.

Hewittia scandens (Milne) Mabb. (1980) 606
Distribution - North America (naturalized in Jamaica), Africa, Asia: Sri Lanka, India, China, Myanmar, Laos, Malaysia, Thailand, Cambodia, Vietnam, Indonesia, Philippines, New Guinea; Pacific Islands (Fang \& Staples 1995). Also in East Timor.

Habitat \& Ecology — In open grasslands, thickets, hedges, teak-forests, grassy dikes and waysides, waste places; both in regions with a feeble and with a pronounced dry season; at low and medium altitudes, from sea level to $1400 \mathrm{~m}$ (Van Ooststroom \& Hoogland 1953). Specimens from Timor were found at 400 and c. $460 \mathrm{~m}$

\section{IPOMOEA L. (1753) 159}

\section{Key to the species of Ipomoea}

1. Sepals distinctly awned at or below the apex, awn straight or curved. Corolla salver-shaped with a long and narrow tube. Stamens and style exserted . . . . . . . . . . . . . 2

1. Sepals not distinctly awned at or below the apex, whether or not mucronulate. Corolla mostly funnel-shaped, or campanulate, or sometimes salver-shaped. Stamens and style mostly included, sometimes exserted . . . . . . . . 4 4

2. Corolla c. $3-4.5 \mathrm{~cm}$ long, scarlet, rarely pure white, tube distinctly widened above the middle. Outer sepals $2-4.5 \mathrm{~mm}$ long (awn excluded), inner ones 3-6 mm (awn excluded)

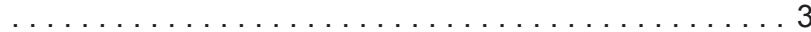

2. Corolla $7-12 \mathrm{~cm}$ long, white with greenish bands, tube not or only slightly widened above the middle. Outer sepals 5-12 $\mathrm{mm}$ long (awn excluded), inner ones 7-15 mm (awn excluded) . . . . . . . . . . . . . . . . . . 2. alba

3. Leaves pinnately divided, segments linear-lanceolate, linear or filiform . . . . . . . . . . . . . . . . 19. I. quamoclit

3. Leaves cordate, entire, angled or palmately lobed, not pinnately divided .............. 10. hederifolia

4. Corolla $10 \mathrm{~cm}$ long or longer, salver-shaped with a long and narrow tube, white, or with greenish or reddish midpetaline bands. Seeds hairy. Large twiners . . . . . . . . . 5

4. Corolla usually less than $10 \mathrm{~cm}$ long, funnel-shaped or campanulate, rarely salver-shaped, in the latter case not longer than c. $7 \mathrm{~cm}$. Seeds hairy or glabrous. Large to small twiners, or prostrate to erect plants . . . . . . . 7

5. Stamens inserted near the mouth of the corolla-tube. Sepals subequal or outer ones slightly longer than the inner ones $\ldots \ldots \ldots \ldots \ldots$ 1. I. aculeata var. mollissima

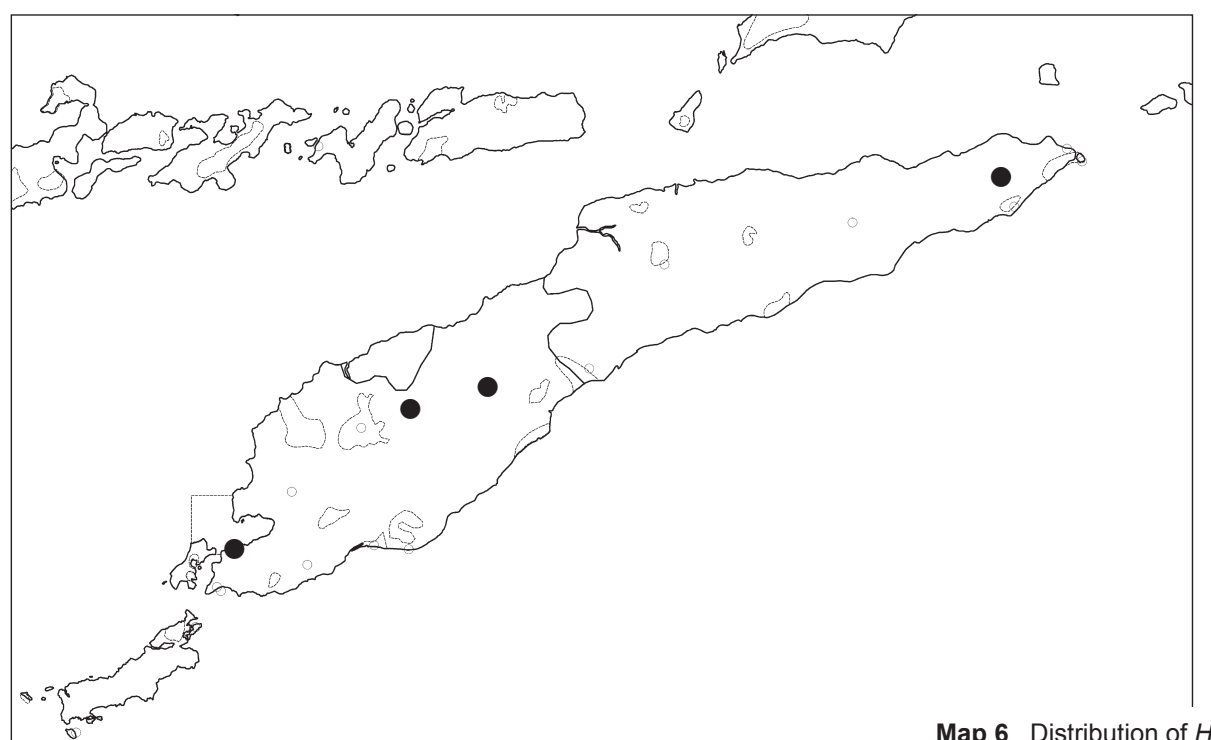

Map 6 Distribution of Hewittia malabarica (L.) Suresh 
5. Stamens inserted near the base of the corolla-tube. Outer sepals slightly or much shorter than the inner ones . . 6

6 . Stamens exserted. Corolla white or with reddish midpetaline bands, 11-14 cm long. Leaves mostly (3-)5(-7)-lobed, rarely entire. Outer sepals much shorter than inner ones. Stems terete or angular, often longitudinally wrinkled, smooth or rarely muricated . . . . . . 22. I. trichosperma

6. Stamens included. Corolla white with greenish bands, 9-12 $\mathrm{cm}$ long. Leaves mostly entire. Outer sepals mostly slightly shorter than inner ones. Stems terete, smooth or minutely verrucose . . . . . . . . . . . . . 25. I.lacea

7. Sepals entirely glabrous, sometimes muricated ... . 8

7. Sepals hairy on the outer surface, or fimbriate at the margins $\ldots \ldots \ldots \ldots \ldots \ldots \ldots \ldots \ldots \ldots \ldots \ldots \ldots \ldots \ldots \ldots$

8. Leaves palmately lobed to palmately compound .... 9 9

8. Leaves not palmately divided . . . . . . . . . . . 11

9. Leaves palmately divided to the base. Pseudostipules (small leaves of the axillary shoot) often present .....

6. I. cairica

9. Leaves palmately lobed often beyond the middle, but never to the base. Pseudostipules absent . . . . . . . . 10

10. Stems twining. Sepals not mucronulate. Seeds with long woolly-sericeous easily detaching hairs 11 . I. mauritiana

10. Stems prostrate, rooting at the nodes. Inner sepals distinctly mucronulate. Seeds glabrous ... . . . . 4. I. batatas

11. Large woody twiner, stems stout. Flowers in axillary panicles . . . . . . . . . . . . . 21. I. sumatrana

11. Smaller, mostly herbaceous twiners with thin stems, or prostrate plants. Flowers in few- to several-flowered, peduncled, axillary cymes, or solitary in the leaf-axils . . 12

12. Corolla salver-shaped . . . . . . . 20. I. sagittifolia

12. Corolla funnel-shaped . . . . . . . . . . . . . 13

13. Corolla up to $2.5 \mathrm{~cm}$ long ......... 13. I. obscura

13. Corolla $3 \mathrm{~cm}$ or longer . . . . . . . . . . . . . . . 14

14. Plants aquatic or growing in marshy places. Stems mostly trailing and rooting, or floating; thick, soft, fistulose or spongy ...................... 3. I. aquatica

14. Terrestrial plants. Stems twining or trailing; not thick, soft, fistulose or spongy . . . . . . . . . . . . 15

15. Stems mostly twining $\ldots \ldots \ldots \ldots \ldots \ldots \ldots$

15. Stems trailing and mostly rooting at the nodes, rarely twin-

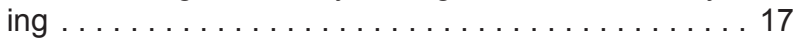

16. Corolla yellow, apical parts of the midpetaline bands pubescent. Seeds tomentose. Sepals 5-6.5 mm with attenuate, broadly rounded to truncate, slightly emarginate, mucronulate apex . . . . . . . . . . . . . . 14. I. ochracea

16. Corolla sky blue with a paler or white tube, entirely glabrous. Seeds glabrous, puberulent or pilose along the edges only. Sepals 4.5-6 mm long, without a distinct mucro

23. I. tricolor

17. Leaves subcoriaceous or fleshy; emarginate or sometimes truncate at the apex. Stems 5-30 m long, containing milky juice ........ 15. I. pes-caprae subsp. brasiliensis

17. Leaves herbaceous, broadly ovate-orbicular in outline, attenuate towards the acute or obtuse apex. Stems 1-5 m, without milky juice . . . . . . . . . . . . 4. I. batatas

18. Flowers axillary. Peduncles very short, or absent. Corolla less than $1.5 \mathrm{~cm}$ long . . . . . . . . . . . . . 19

18. Flowers not axillary. Peduncles well-developed. Corolla $1.5 \mathrm{~cm}$ long, or mostly longer . . . . . . . . . . 21

19. Erect or ascending herb. Leaf-base acute, attenuate into the petiole. Corolla glabrous . . . . . . 17. I. polymorpha

19. Twining or prostrate herbs. Leaf-base cordate. Corolla with midpetaline bands hairy or at least pilose towards the apex ................... 20
20. Ovary and capsule hairy. Outer sepals linear-acuminate, base ovate. Pedicels none or very short, up to $3 \mathrm{~mm}$. Corolla pink or purple, c. 7-9 mm long .... . 9. I. eriocarpa

20. Ovary and capsule glabrous. Outer sepals deltate-lanceolate, base auriculate. Pedicels $8-15 \mathrm{~mm}$. Corolla white, up to $19 \mathrm{~mm}$ long . . . . . . . . . . . . . . 5. I. biflora

21. Flowers aggregated at the end of the peduncle, involucrate by large bracts . . . . . . . . . 16. I. pes-tigridis

21. Flowers whether or not aggregate at the end of the peduncle, not distinctly involucrate . . . . . . . . . . 22

22. Sepals up to $4 \mathrm{~mm}$ long ........... 13. I. obscura

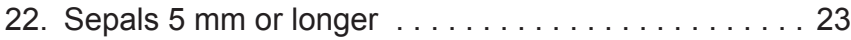

23. Outer sepals orbicular, broadly rounded at the apex. Corolla with puberulent tube and midpetaline bands. Seeds sericeous-pubescent . . . . . 7. I. carnea subsp. fistulosa

23. Outer sepals mostly acute, sometimes subobtuse. Corolla glabrous outside. Seed puberulent or glabrous, sometimes pilose at the hilum or at the edges only . . . . . . . 24

24. Sepals long-attenuate, or long and linear-acuminate at the apex, herbaceous . . . . . . . . . . . . 25

24. Sepals acute or subobtuse, not long-attenuate towards the apex, herbaceous, membranaceous or coriaceous . . 26

25. Sepals almost linear, acute, 8-15 mm long. Corolla up to $3 \mathrm{~cm}$ long, purple. . . . . . . . . . . . . 8. I. decaisnei

25. Sepals lanceolate, $17-25 \mathrm{~mm}$ long. Corolla $5-6 \mathrm{~cm}$ long, pale to bright blue with whitish tube (fading to pink in age) . . . . . . . . . . . . . . . . . 12. I. nil

26. Outer sepals not mucronulate. Corolla $4-6 \mathrm{~cm}$. Sepals 11-16 $\mathrm{mm}$, margins not ciliate nor fimbriate .

18. I. purpurea

26. Sepals mucronulate. Corolla $1.5-4(-5) \mathrm{cm}$. Sepals $5-6$ $\mathrm{mm}$, margins ciliate or fimbriate . . . . . . . 27

27. Sepals glabrous or sparsely hairy on the back, the margins always distinctly fimbriate. Corolla funnel-shaped c. 1.75-2 $\mathrm{cm}$ long, with short obtuse, mucronulate lobes . . . . . . .

24. I. triloba

27. Sepals entirely glabrous, or pilose on the back, the margins ciliate. Corolla campanulate to funnel-shaped, c. $3-4.5 \mathrm{~cm}$ long, not distinctly lobed .......... 4. I. batatas

\section{Ipomoea aculeata Blume}

Ipomoea aculeata Blume (1826) 715; Kalkman (1955) 216.

\section{a. var. mollissima (Zoll.) Hallier f. ex Ooststr. — Map 7}

Ipomoea aculeata Blume var. mollissima (Zoll.) Hallier f. ex. Ooststr. (1940) 574; Malm (1934) 286; Ooststr. (in Ooststr. \& Hoogland 1953) 486 Calonyction mollissimum Zoll. (1854) 128, 131.

Distribution — In continental Asia: China, Myanmar and Thailand (Fang \& Staples 1995). In Malesia: Middle and East Java, Madura, Lesser Sunda Islands (Lombok, Sumbawa, Timor, Alor) and Philippines (Luzon) (Van Ooststroom \& Hoogland 1953).

Habitat \& Ecology - In thickets and thin forests, from sea level to $700 \mathrm{~m}$.

Vernacular name - Lak-laku, non hau kase (Dawan).

Uses - The leaves are used as purgative and as a substitute for soap (Heyne in Van Ooststroom \& Hoogland 1953).

\section{Ipomoea alba L. - Map 7}

Ipomoea alba L. (1753) 161; Ooststr. (in Ooststr. \& Hoogland 1953) 480 Ipomoea bona-nox L. (1762) 228; Fawc. (1885) 511.

Calonyction speciosum Choisy (1834) 441; Decne. (1834) 389; Span. (1841) 338. 


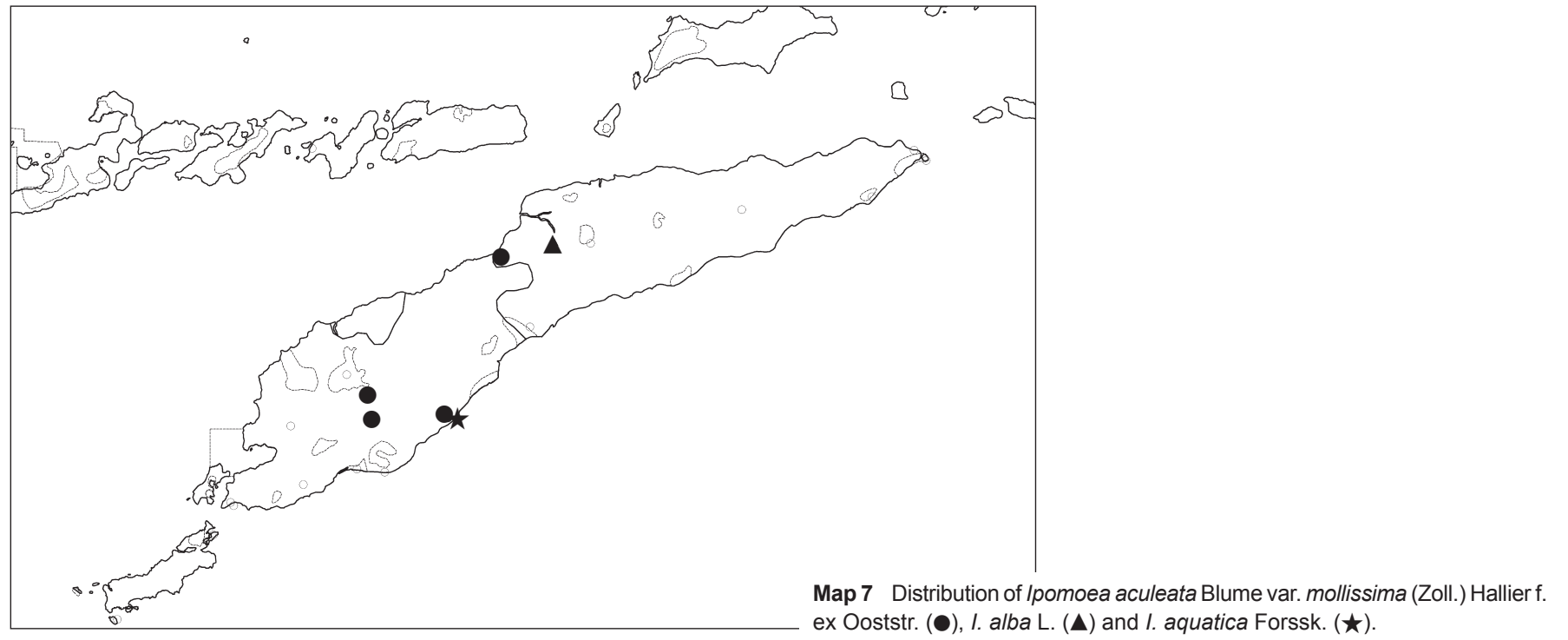

Distribution - Circumtropical: originally in tropical America, in Malesia cultivated in gardens and run wild (Van Ooststroom \& Hoogland 1953).

Habitat \& Ecology — In thickets, hedges, along waysides and edges of forests; widely distributed in the settled areas at low and medium altitudes; cultivated and run wild (Van Ooststroom \& Hoogland 1953).

Uses - The whole plant is used for treating snakebite (Fang \& Staples 1995). The young leaves are eaten as a vegetable Heyne in Van Ooststroom \& Hoogland 1953); the dried flowers are used in pies and in kimlo (Chinese vegetable soup) (Ochse in Van Ooststroom \& Hoogland 1953). It is often cultivated in gardens for its nocturnal, fragrant flowers.

\section{Ipomoea aquatica Forssk. - Map 7}

Ipomoea aquatica Forssk. (1775) 44; Fawc. (1885) 511; Ooststr. (in Ooststr. \& Hoogland 1953) 473; Kalkman (1955) 216.

Ipomoea reptans Poir. (1813) 460; Span. (1841) 339; Miq. (1856) 601.

Ipomoea repens Roth (1821) 110

Distribution - Circumtropical, throughout Malesia (Van Ooststroom \& Hoogland 1953)

Habitat \& Ecology — In moist, marshy or inundated localities, in shallow pools, ditches, wet rice-fields, forming dense masses; also along waysides, from sea level to $1000 \mathrm{~m}$; wild and cultivated; the species is easily propagated by cuttings (Van Ooststroom \& Hoogland 1953).

Vernacular names - Canco (Tetum?); kangkung (Indonesian).

Uses - Used as a laxative, recommended for piles (Burkill, Read, Valkenburgh \& Bunyapraphatsara in Austin 2007) and said to have a nerve-calming effect (Naples in Austin 2007), among other medicinal uses. It is also an excellent palatable vegetable, especially the young shoots and leaves (Burkill, Heyne in Van Ooststroom \& Hoogland 1953), and it is very popular as an addition to other foods at meals (Cornelius et al. in Austin 2007). It is used for forage (Fang \& Staples 1995), but in limited quantities, due to its laxative effect on the animals (Austin 2007).

\section{Ipomoea batatas (L.) Lam. - Map 8}

Ipomoea batatas (L.) Lam. (1792) 465; Span. (1841) 340; Ooststr. (in Ooststr. \& Hoogland 1953) 469

Convolvulus batatas L. (1753) 154

Distribution - Throughout the tropical and subtropical regions of both hemispheres (Van Ooststroom \& Hoogland 1953).
Habitat \& Ecology - Cultivated in gardens by the houses; occasionally wild, escaped from cultivation; at low and medium altitudes (Van Ooststroom \& Hoogland 1953)

Vernacular name - Sekal dila (Timor: unknown dialect).

Uses - Used for poulticing (Van Ooststroom \& Hoogland 1953). Widely cultivated for its edible tubers, which are an important source of starch (Fang \& Staples 1995); the young shoots are also eaten as a salad (Van Ooststroom \& Hoogland 1953). The stems and leaves can be used as livestock forage and the tubers are raw material for producing alcohol (Fang \& Staples 1995).

\section{Ipomoea biflora (L.) Pers.}

Ipomoea biflora (L.) Pers. (1805) 183.

Convolvulus biflorus L. (1753) 1668.

Ipomoea plebeia R.Br. (1810) 484; Ooststr. (in Ooststr. \& Hoogland 1953) 463; Kalkman (1955) 216.

Distribution - East Africa, India, China, Myanmar, Vietnam, Japan (Ryukyu Islands), North Australia (Fang \& Staples 1995). In Malesia: Java, Kangean, Lesser Sunda Islands (Lombok, Sumbawa, Timor), South Celebes, Philippines (Van Ooststroom \& Hoogland 1953)

Habitat \& Ecology — In grasslands, dry thickets, in regions subject to a pronounced dry season, from sea level to $600 \mathrm{~m}$; rare (Van Ooststroom \& Hoogland 1953).

Uses - The whole plant has several medicinal uses (Fang \& Staples 1995).

Note - Although Van Ooststroom (Van Ooststroom \& Hoogland 1953) preferred to use I. plebeia R.Br., Staples \& Jarvis (2006) dealt satisfactorily with this nomenclature issue, proposing I. biflora (L.) Pers. as the correct name for this species.

\section{Ipomoea cairica (L.) Sweet - Map 8}

Ipomoea cairica (L.) Sweet (1827) 287; Ooststr. (in Ooststr. \& Hoogland 1953) 478.

Convolvulus cairicus L. (1759) 922.

Distribution - South America, Africa, Southwest Asia, Sri Lanka, Pakistan, India, Nepal, China, Thailand, Myanmar, Vietnam, Malaysia, Indonesia, Philippines, New Guinea, Pacific Islands, Japan (Ryukyu Islands) (Fang \& Staples 1995). Also in East Timor

Habitat \& Ecology - In thickets, roadsides, waste places, cultivated areas, sunny meadows in lowlands (Fang \& Staples 1995). A specimen from East Timor was found at $400 \mathrm{~m}$. 


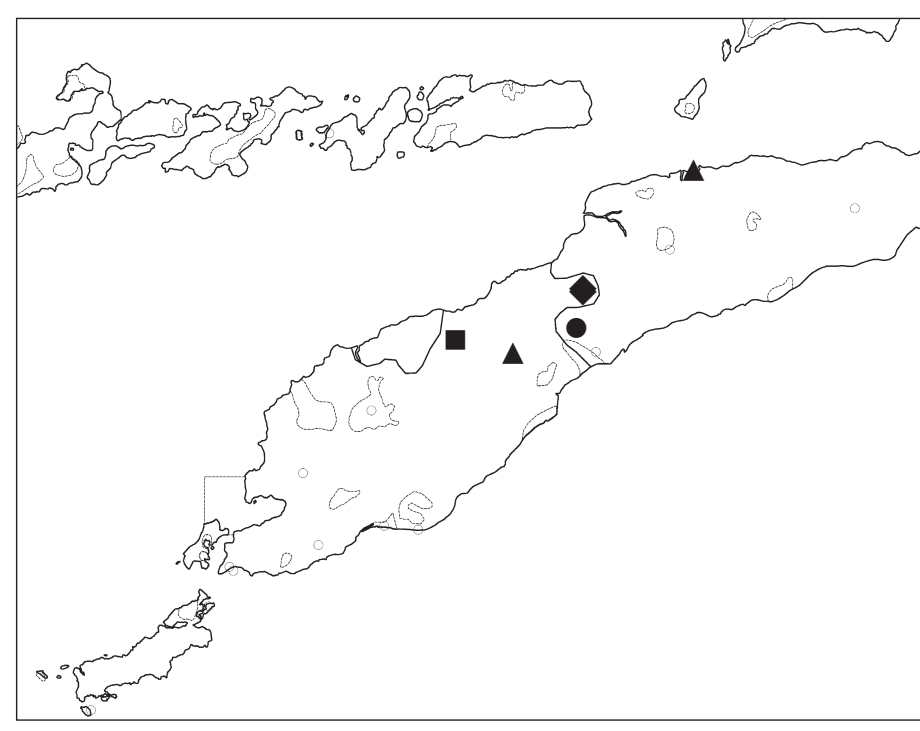

Uses - The whole plant is used for treating external infections (Fang \& Staples 1995). Compounds with antiviral activity (namely anti-HIV) can be extracted from this plant (Mathée et al. 1999).

7. Ipomoea carnea Jacq. subsp. fistulosa (Mart. ex Choisy) D.F.Austin - Map 8

Ipomoea carnea Jacq. subsp. fistulosa (Mart. ex Choisy) D.F.Austin (1977) 237.

Ipomoea fistulosa Mart. ex Choisy (1845) 349.

Ipomoea crassicaulis (Benth.) B.L.Rob. (1916) 530; Ooststr. (in Ooststr. \& Hoogland 1953) 485.

Distribution - North America, South America, Sri Lanka, Pakistan, India, Nepal, China, Myanmar, Thailand, Cambodia, Indonesia, New Guinea, Pacific Islands, Japan (Ryukyu Islands) (Fang \& Staples 1995). Also in East Timor.

Habitat \& Ecology - In hydric sites, particularly ditches, lake margins, marshes, river edges and 'mattorales' in South America; also in Hawaii and the tropics of the Old World (Austin 1977).

\section{Ipomoea decaisnei Ooststr. — Map 8}

Ipomoea decaisnei Ooststr. (1940) 503; Ooststr. (in Ooststr. \& Hoogland 1953) 466; Kalkman (1955) 216.

Pharbitis variifolia Decne. (1834) 390; Span. (1841) 338.

Distribution - Malesia: East Java, Madura, Southwest and Southeast Celebes (Buton IsI.), Lesser Sunda Islands (Lombok, Sumbawa, Timor) (Van Ooststroom \& Hoogland 1953).

Habitat \& Ecology — In thickets, hedges, waysides, apparently restricted to regions subject to a pronounced dry period, from sea level to 750 m (Van Ooststroom \& Hoogland 1953).

Vernacular name - Daun tapahaik (Timor: unknown dialect).

\section{Ipomoea eriocarpa $\mathrm{R} . \mathrm{Br}$.}

Ipomoea eriocarpa R.Br. (1810) 484; Ooststr. (in Ooststr. \& Hoogland 1953) 462; Kalkman (1955) 216.

Ipomoea hispida (Vahl) Roem. \& Schult. (1819) 238

Distribution - Africa, Sri Lanka, Pakistan, India, Nepal, China, Myanmar, Thailand, Cambodia, Laos, Vietnam, Malaysia, Indonesia, New Guinea, Philippines, North Australia (Fang \& Staples 1995).

Habitat \& Ecology — In open grasslands, grassy waysides, thickets, hedges, fields and occasionally in secondary forests; on periodically dry soil; in regions with a fairly pronounced dry season; from sea level to 1300 m (Van Ooststroom \& Hoogland 1953).

\section{Ipomoea hederifolia L. - Map 8}

Ipomoea hederifolia L. (1759) 925; Ooststr. (1958) 563 Ipomoea angulata Lam. (1792) 464; Ooststr. (in Ooststr. \& Hoogland 1953) 481.

Distribution - Native to tropical America, now circumtropical; in Malesia cultivated and run wild (Van Ooststroom \& Hoogland 1953).

Habitat \& Ecology - Run wild in waste places, fields, grasslands, thickets and thin forests; up to $1200 \mathrm{~m}$ (Van Ooststroom \& Hoogland 1953).

Uses - Cultivated in gardens for ornamental purposes (Van Ooststroom \& Hoogland 1953).

\section{Ipomoea mauritiana Jacq.}

Ipomoea mauritiana Jacq. (1791) 216; Ooststr. (1972) 941 Ipomoea paniculata R.Br. (1810) 486, auct. non Burm.f. (1768); Span. (1841) 340.

Ipomoea digitata auct. non L. (1759) 924; Fawc. (1885) 511; Ooststr. (in Ooststr. \& Hoogland 1953) 483; Kalkman (1955) 216.

Distribution - Sri Lanka, Myanmar, Thailand, Cambodia, Laos, Vietnam, China, Malaysia, Indonesia, New Guinea, Philippines, Pacific Islands, Japan (Ogasawara and Ryukyu Islands) (Fang \& Staples 1995).

Habitat \& Ecology - In thickets on the beach, but also in the interior, in waste places, thickets, hedges, savannah-forests, teak-forests, alang-alang fields, and along waysides; also cultivated; from sea level to 700 m (Van Ooststroom \& Hoogland 1953).

Vernacular name - Laluli (Timor: unknown dialect) (Van Ooststroom \& Hoogland 1953).

Uses - The leaves and roots are used externally for treating tuberculosis, as well as external and breast infections (Fang \& Staples 1995). The root alone is pounded and applied for swellings (Peninsular Malaysia); moreover it is said to be cathartic (Van Ooststroom \& Hoogland 1953). The plant is also cultivated for ornamental purposes. 


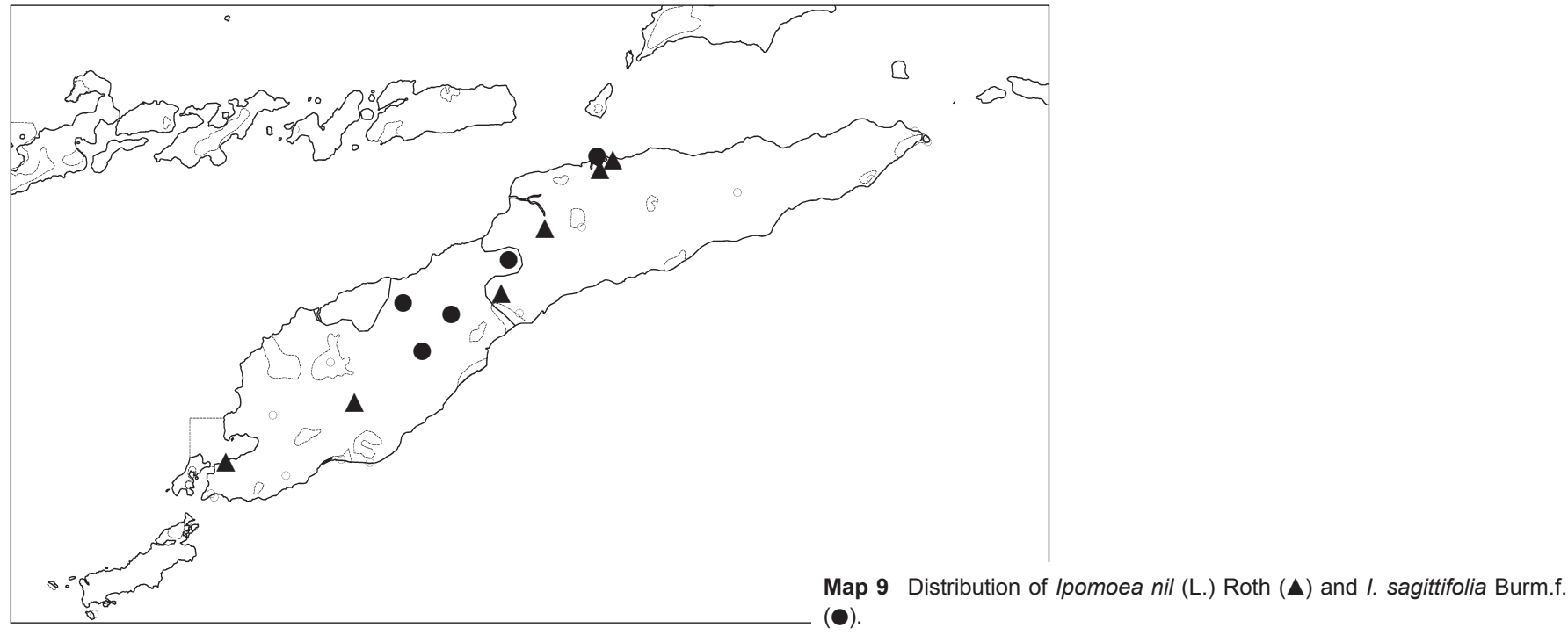

12. Ipomoea nil (L.) Roth - Map 9

Ipomoea nil (L.) Roth (1797) 36; Ooststr. (in Ooststr. \& Hoogland 1953) 465; Kalkman (1955) 216.

Convolvulus nil L. (1762) 219.

Ipomoea setosa Blume (1826) 714; Span. (1841) 340

Pharbitis nil (L.) Choisy (1834) 439; Decne. (1834) 388; Span. (1841) 338 Ipomoea trichocalyx Steud. (1840) 819; Miq. (1856) 611; Fawc. (1885) 511. Ipomoea hederacea auct. non Jacq. (1787) 124, pl. 36; Fawc. (1885) 511.

Distribution - Pantropical; native in America and introduced in Asia in the16th century (Austin 1986).

Habitat \& Ecology - In waysides, hedges, thickets and grasslands, from sea level to $1300 \mathrm{~m}$ (Van Ooststroom \& Hoogland 1953).

Vernacular name - Hiluk talin pana (unknown dialect).

Uses - The seeds are said to be purgative. The plant is cultivated in gardens for ornamental purposes (Van Ooststroom \& Hoogland 1953). In Timor, used as a remedy for wounds, and in the preparation of black paint (Friedberg 412).

Note - A few specimens from Timor had been identified as $I$. hederacea Jacq., but were revised for this study and reidentified as $I$. nil. The two species can be told apart mainly by the shape of the sepals: in I. hederacea they constrict abruptly and then taper towards the tip, whereas in I. nil they taper gradually (Heine 1963, Acevedo-Rodriguez 2003, Hawthorne \& Jongkind 2006). This is not always easily observed, especially in herbarium specimens, which has caused some confusion between the two species.
13. Ipomoea obscura (L.) Ker Gawl. - Map 10

Ipomoea obscura (L.) Ker Gawl. (1817) t. 239; Decne. (1834) 392; Miq. (1856) 611; Fawc. (1885) 511; Ooststr. (in Ooststr. \& Hoogland 1953) 471; Kalkman (1955) 216

Convolvulus obscurus L. (1762) 220.

Ipomoea insuavis Blume (1826) 716.

Distribution - East tropical Africa, Mascarene Islands, tropical Asia, throughout Malesia to North Australia and Fiji (Van Ooststroom \& Hoogland 1953).

Habitat \& Ecology — In grasslands, thickets, hedges, thin forests, waysides, waste ground; occasionally on sandy soil near the sea; from sea level to $1300 \mathrm{~m}$ (Van Ooststroom \& Hoogland 1953). Specimens from Timor were collected at 750-760 m.

Uses - Leaves, together with those of Argyreia mollis (Burm.f.) Choisy, are used against sores (Heynes in Van Ooststroom \& Hoogland 1953). Watt (1890) noted that in India, the leaves when toasted, powdered and boiled with a certain portion of ghi were considered a valuable application in aphthous infections.

\section{Ipomoea ochracea (Lindl.) G.Don - Map 10}

Ipomoea ochracea (Lindl.) G.Don (1838) 270; Ooststr. (1972) 941. Convolvulus ochraceus Lindl. (1826) t. 1060.

Ipomoea ochroleuca Span. (1841) 340; Ooststr. (in Ooststr. \& Hoogland 1953) 472; Kalkman (1955) 216; 'ochralacea' Miq. (1856) 614.

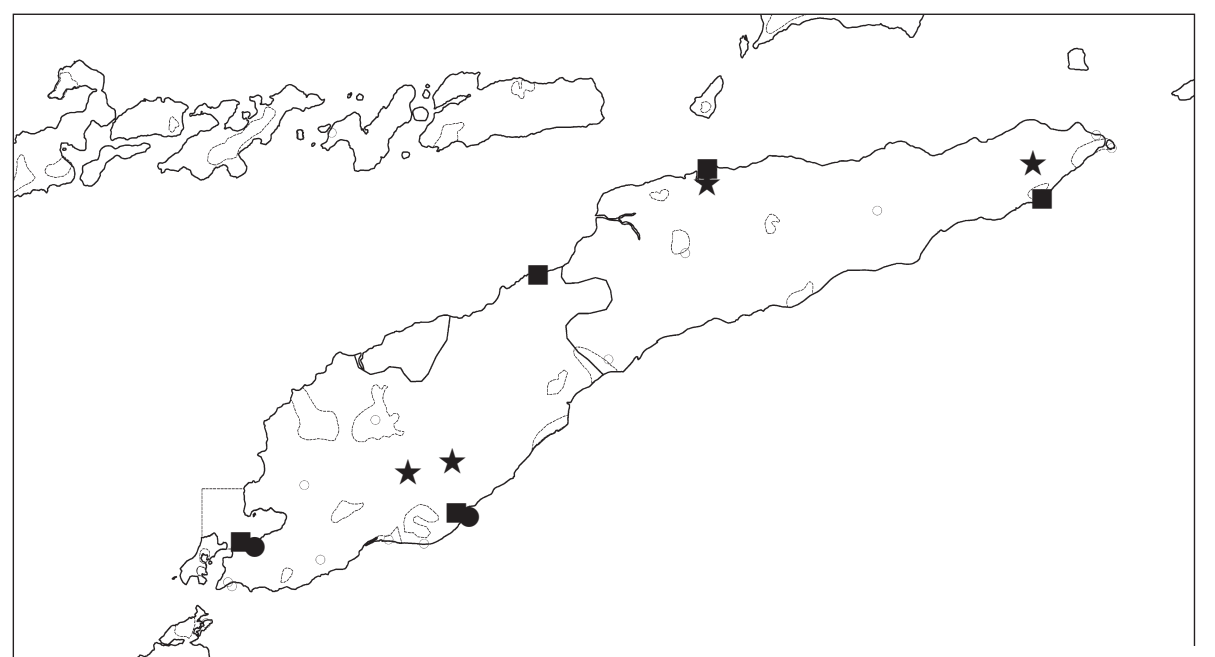

Map 10 Distribution of Ipomoea obscura (L.) Ker Gawl, ( $\star$ ) I. ochracea (Lindl.) G.Don (๑) and I. pes-caprae (L.) R.Br. subsp. brasiliensis (L.) Ooststr. (ם). 


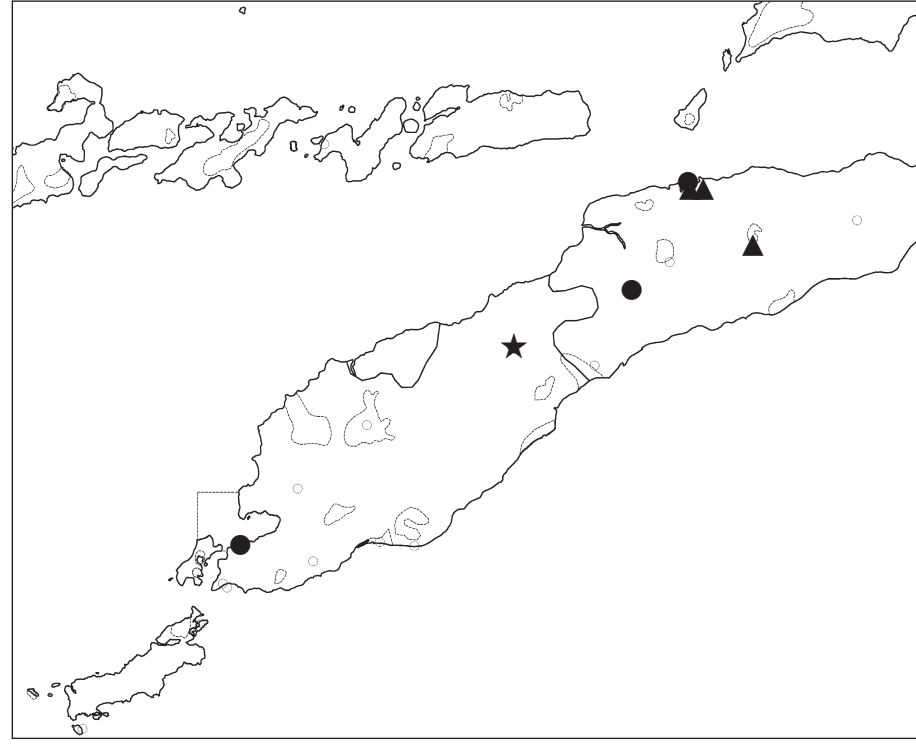

Distribution - Tropical Africa, in Malesia: Lesser Sunda Islands (Timor, Alor), North Borneo; New Caledonia (Van Ooststroom 1958).

Habitat \& Ecology - In Timor on rocks near the sea (Van Ooststroom 1958).

\section{Ipomoea pes-caprae (L.) R.Br.}

Ipomoea pes-caprae (L.) R.Br. (1816) 477; Miq. (1856) 602; Fawc. (1885) 511; Kalkman (1955) 216

Convolvulus pes-caprae L. (1753) 159.

Ipomoea maritima (Desr.) R.Br. (1810) 486; Span. (1841) 339

a. subsp. brasiliensis (L.) Ooststr. (1940) 533. - Map 10

Convolvulus brasiliensis L. (1753) 159.

Distribution - Circumtropical, the most common subspecies throughout Malesia (Van Ooststroom \& Hoogland 1953).

Habitat \& Ecology - On and immediately behind seashores, occasionally in the interior, along waysides, ditches and canals, from sea level up to 600 m (Van Ooststroom \& Hoogland 1953).

Vernacular name - Tai ilaça (Timor: unknown dialect).

Uses - The seeds are said to be a good remedy for stomachache and cramp; in East Malaysia the leaves are made into poultices, which are used to ripen boils and applied to swellings, wounds, ulcers and such. The juice of the stems is known to be used in the Island of Nusa Kembagan (South Java) as a medicine against bites and stings of fishes. The species may be useful as a sand-binder (Burkill, Heyne in Van Ooststroom \& Hoogland 1953).

\section{Ipomoea pes-tigridis L. - Map 11}

Ipomoea pes-tigridis L. (1753) 162; Span. (1841) 340; Ooststr. (in Ooststr. \& Hoogland 1953) 467; Kalkman (1955) 216.

Distribution - East tropical Africa, Mascarene Islands, continental tropical Asia, throughout Malesia (Van Ooststroom \& Hoogland 1953).

Habitat \& Ecology - In grasslands, waste places, fields, thickets, occasionally in teak-forest, also on sandy soil near the sea; from sea level to $1000 \mathrm{~m}$ (Van Ooststroom \& Hoogland 1953).

\section{Ipomoea polymorpha Roem. \& Schult. - Map 11}

Ipomoea polymorpha Roem. \& Schult. (1819) 254; Ooststr. (in Ooststr. \& Hoogland 1953) 464; Kalkman (1955) 216.

Ipomoea pumila Span. (1841) 341; Fawc. (1885) 511. - Type: Timor, s.c. (?) 45 (holo L)

Distribution - Ethiopia, India (?), Indo-China, and Taiwan to Northeast Australia, in Malesia: East Java, Madura, Lesser Sunda Islands (Sumba, Flores, Timor), Philippines (Luzon), Northeast New Guinea and Thursday Island (Van Ooststroom \& Hoogland 1953)

Habitat \& Ecology — In grasslands, grassy waysides, fields, sandy plains, dunes; in the lower parts of the islands with a strong dry monsoon; on hard or stony soil, in sunny localities, from sea level to c. 100 m (Van Ooststroom \& Hoogland 1953).

\section{Ipomoea purpurea (L.) Roth}

Ipomoea purpurea (L.) Roth (1787) 27; Ooststr. (in Ooststr. \& Hoogland 1953) 465.

Convolvulus purpureus L. (1762) 219.

Distribution — Sri Lanka, Pakistan, Nepal, China, Indonesia, Philippines; native to North and South America, introduced and naturalized worldwide (Fang \& Staples 1995).

Habitat \& Ecology - Waysides, hedges, fields; from sea level to $2800 \mathrm{~m}$ (Fang \& Staples 1995).

\section{Ipomoea quamoclit L. - Map 11}

Ipomoea quamoclit L. (1753) 159; Span. (1841) 339; Fawc. (1885) 511; Ooststr. (in Ooststr. \& Hoogland 1953) 482; Kalkman (1955) 216. Quamoclit vulgaris Choisy (1834) 434.

Distribution - Circumtropical, in Malesia cultivated and run wild throughout the region (Van Ooststroom \& Hoogland 1953).

Habitat \& Ecology - Run wild in waste places, hedges, thickets, thin forests and along edges of cane and rice-fields, up to 1200 m (Van Ooststroom \& Hoogland 1953). It is quite common all around Timor, where it has been found in mountain slopes and along roads.

\section{Ipomoea sagittifolia Burm.f. - Map 9}

Ipomoea sagittifolia Burm.f. (1768) 50, t. 18, f. 2.

Convolvulus marginatus Desr. (1792) 438.

Ipomoea sepiaria J.Koenig ex Roxb. (1824) 90; Ooststr. (1972) 941. 
Ipomoea verrucosa Blume (1826) 718; Span. (1841) 340.

Ipomoea marginata (Desr.) Verdc. (1987) 658

Ipomoea maxima auct. non (L.f.) Sweet (1830) 372.

Distribution - Africa, Sri Lanka, ?Pakistan, India, China, Myanmar, Thailand, Laos, Vietnam, Malaysia, Indonesia, New Guinea, North Australia, Pacific Islands (Fang \& Staples 1995). Also in East Timor.

Habitat \& Ecology - In coastal or saline soils, grasslands, fields and waste areas (Fang \& Staples 1995). In Malesia not found on the beaches bordering the Indian Ocean, but apparently mostly confined to the clays of muddy seas (Van Ooststroom \& Hoogland 1953). In Timor, up to c. 760 m.

\section{Ipomoea sumatrana (Miq.) Ooststr.}

Ipomoea sumatrana (Miq.) Ooststr. (1940) 571; Ooststr. (in Ooststr. \& Hoogland 1953) 486; Kalkman (1955) 216.

Lettsomia sumatrana Miq. (1861) 560.

Ipomoea repanda auct. non Jacq., Fawc. (1885) 511.

Distribution - Myanmar, China, Thailand, Laos, Malaysia, Indonesia (Fang \& Staples 1995).

Habitat \& Ecology — In thickets, roadsides, forest margins, 100-900 m (Fang \& Staples 1995).

Note - Fawcett (1885) reported I. repanda Jacq. from Timor, citing a specimen by Wiles \& Smith from the BM herbarium. The specimen was examined for this study and matches I. sumatrana, as Van Ooststroom (1940, Van Ooststroom \& Hoogland 1953) suspected.

\section{Ipomoea trichosperma Blume - Map 12}

Ipomoea trichosperma Blume (1826) 710; Malm (1934) 287; Ooststr. (in Ooststr. \& Hoogland 1953) 487; Kalkman (1955) 216. Ipomoea capillata Span. (1841) 340; Fawc. (1885) 511. Calonyction capillatum Miq. (1856) 598

Distribution - Malesia: Java, Celebes (Salajar and Buton Isl.), Lesser Sunda Islands (Sumbawa, Timor, Alor) (Van Ooststroom \& Hoogland 1953).

Habitat \& Ecology - In thickets, hedges and thin forests; near the beach and in the interior; from sea level to $400 \mathrm{~m}$ (Van Ooststroom \& Hoogland 1953).

\section{Ipomoea tricolor Cav. - Map 12}

Ipomoea tricolor Cav. (1795) 5, t. 208; Ooststr. (in Ooststr. \& Hoogland 1953) 478.

Distribution - Mexico, Central America, West Indies, tropical South America, elsewhere cultivated and perhaps occasionally escaped, in Malesia only known from the Peninsular Malaysia (as a garden escape), and Timor, where it is locally frequent in the North Central portion of the island, at $400 \mathrm{~m}$ (Van Ooststroom \& Hoogland 1953).

Habitat \& Ecology - Small plant, found in roadsides and said to be very frequent in some localities of Timor.

Vernacular name - Non luli (Timor: unknown dialect).

\section{Ipomoea triloba L. - Map 12}

Ipomoea triloba L. (1753) 161; Ooststr. (in Ooststr. \& Hoogland 1953) 468.

Distribution - Native to tropical America, now a circumtropical weed; throughout Malesia (Van Ooststroom \& Hoogland 1953).

Habitat \& Ecology — In grasslands, thickets, hedges, waste places, waysides, fields, also in savannah-forests and occasionally on sandy sea-shores, from sea level to $750 \mathrm{~m}$ (Van Ooststroom \& Hoogland 1953).

Vernacular names - Fehuc-fuic (Tetum), naubia-talin (Manbae).

\section{Ipomoea violacea L. - Map 12}

Ipomoea violacea L. (1753) 161.

Calonyction muticum Decne. (1834) 390; Span. (1841) 338; Miq. (1856) 597. Ipomoea tuba (Schltdl.) G.Don (1838) 271; Ooststr. (in Ooststr. \& Hoogland 1953) 487.

Distribution - North America, South America, Africa, Sri Lanka, Thailand, Malaysia, Indonesia, Philippines, New Guinea, North Australia, Pacific Islands, Japan (Van Ooststroom \& Hoogland 1953).

Habitat \& Ecology - Beaches, seaside thickets, edges of brackish rivers and lagoons, near sea level to 100 m (Fang \& Staples 1995).

Note - A specimen from Timor was found at c. $275 \mathrm{~m}$.

\section{Doubtful records}

Ipomoea campanulata L. (1753) 160; Decne. (1834) 391; Span. (1841) 338; Miq. (1856) 606; Fawc. (1885) 511.

The one collection on which the reports of this taxon are based, Meyer (s.n.), has been seen at K, and it has been established that the collection locality is actually 'Timor-laut' (Tanimbar islands). Therefore there seems to be no evidence that the species really occurs in Timor.

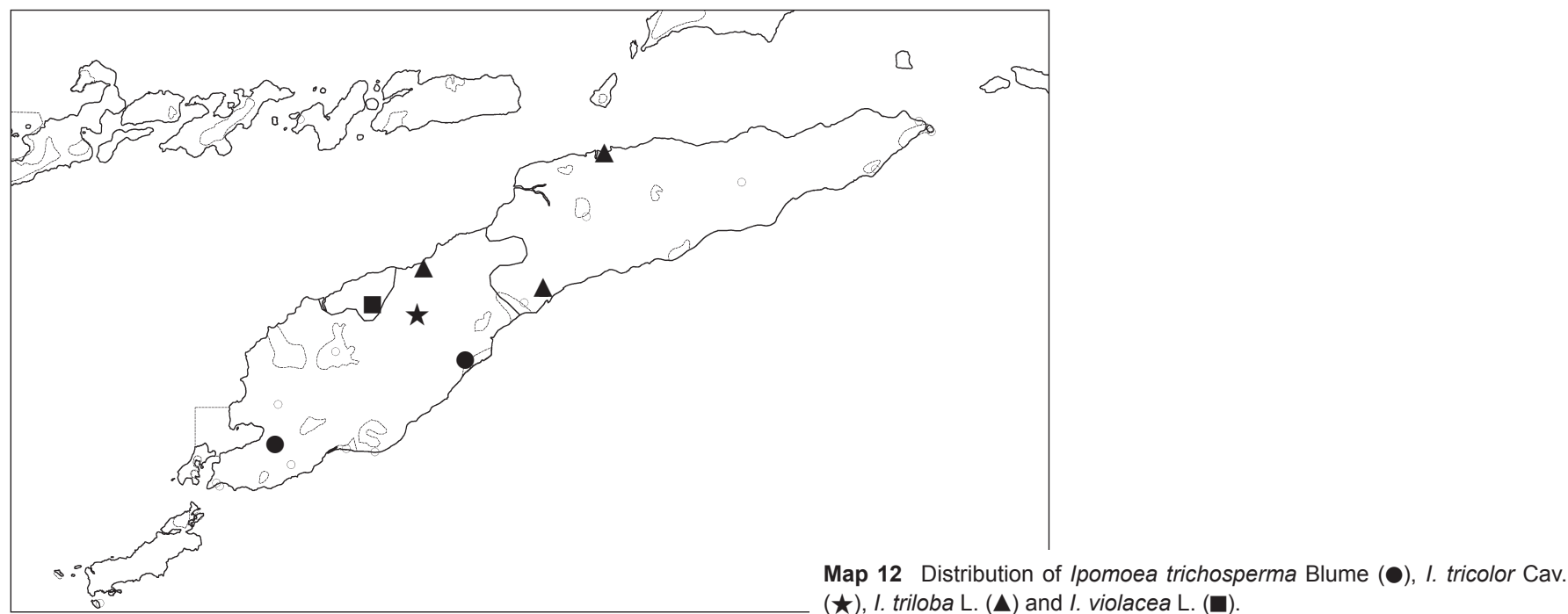

$(\star)$, I. triloba L. (A) and I. violacea L. (ם). 


\section{Insufficiently known}

Ipomoea muricata (L.) Jacq. (1798) 40, t. 23; Miq. (1856) 608.

Miquel lists this species as occurring in Timor but no specimens or other references have been cited or found by the authors that could support this statement. In Miquel's work, I. aculeata is confusingly cited as a synonym and the description used seems a mixed concept of $I$. aculeata and $I$. muricata.

Ipomoea aculeata var. mollissima is known to exist in Timor, but whether I. muricata could actually have been found in the island is yet to be confirmed.

\section{Unidentified specimens}

Two specimens from Timor remain to be identified at species level - Kooy 283 (L!) and Verdial 26 (LISC!) - due to the lack of relevant taxonomical characters. Kooy 283 was not possible to identify because it lacks leaves and has only dehisced fruits. Without knowing the leaf morphology or details about the corolla or flower buds, we were unable to place this specimen. However, as the sepals are awned, it is possibly one of the following three species with this feature that occur in Timor: I. alba, I. hederifolia or I. quamoclit.

The presence of pseudostipules in Verdial 26 suggests it could be related to $I$. cairica. The particular shape of the leaves (5lobed, with a longer and broader central lobe) resembles that of I. tuberculata Ker Gawl. However, the leaves are not as deeply lobed and the lobes are somewhat broader than in I. tuberculata. Comparison with more taxa is necessary to establish the identity of this specimen.

\section{JACQUEMONTIA Choisy (1834) 476}

\section{Key to the species of Jacquemontia}

1. Two outer sepals ovate-lanceolate to ovate, attenuate to the base, acuminate at the apex ......... 1. J. paniculata

1. Two outer sepals broadly ovate, cordate or rounded at the base, acute to short-acuminate at the apex 2. J. zollingeri

Note - It is rather difficult to tell these two species apart. The specimens studied exhibit reasonably high levels of variation in characters such as the shape of sepals or density of indumentum and, as Van Ooststroom suggests, it might be that both should be considered varieties of the same species. Further studies on the morphological variability of these species are necessary.

\section{Jacquemontia paniculata (Burm.f.) Hallier f. - Map 13}

Jacquemontia paniculata (Burm.f.) Hallier f. (1893a) 541. Ipomoea paniculata Burm.f. (1768) 50, pl. 21, f. 3.

\section{Key to the varieties of Jacquemontia paniculata}

1. Leaves glabrous, or short-pilose and glabrescent. Stems mostly glabrescent ........... a. var. paniculata

1. Leaves mostly densely tomentose, finally glabrescent. Stems covered with a dense yellowish brown tomenthum ...... $\ldots \ldots \ldots \ldots \ldots \ldots$ b. var. tomentosa

\section{a. var. paniculata}

Convolvulus parviflorus Vahl (1794) 29; Decne. (1834) 392; Span. (1841) 341; Miq. (1856) 622; Fawc. (1885) 511.

Distribution - Tropical East Africa, Madagascar and adjacent islands to SE Asia, tropical Australia, and New Caledonia; throughout Malesia (Van Ooststroom \& Hoogland 1953).

Habitat \& Ecology — In thickets, secondary forests, teakforests, grassy places, along fields, hedges, waysides; often on dry-soil; from sea level to c. 600(-880) m (Van Ooststroom \& Hoogland 1953).

\section{b. var. tomentosa (Warb.) Ooststr.}

Jacquemontia paniculata var. tomentosa (Warb.) Ooststr. (in Ooststr. \& Hoogland 1953) 432.

Convolvulus parviflorus Vahl var. tomentosus Warb. (1894) 207.

Distribution - North Australia and Queensland, in Malesia: Lesser Sunda Islands (Sumba, Timor), East New Guinea, Philippines (Apo Island in Mindoro Strait) (Van Ooststroom \& Hoogland 1953).

Habitat \& Ecology — In grass-fields, on rocks; from sea level to c. $1200 \mathrm{~m}$ (Van Ooststroom \& Hoogland 1953).

\section{Jacquemontia zollingeri (Choisy) Hallier $f$.}

Jacquemontia zollingeri (Choisy) Hallier f. (1893a) 543; Ooststr. (in Ooststr. \& Hoogland 1953) 433; Kalkman (1955) 216.

Convolvulus zollingeri Choisy in Zoll. (1854) 130, 132.

\section{Key to the varieties of Jacquemontia zollingeri}

1. Stems, leaves and inflorescences pubescent to tomentose. Peduncles $2-15 \mathrm{~mm}$ long. Corolla pale lilac . . . . . . . . $\ldots \ldots \ldots \ldots \ldots \ldots \ldots$. var. zollingeri

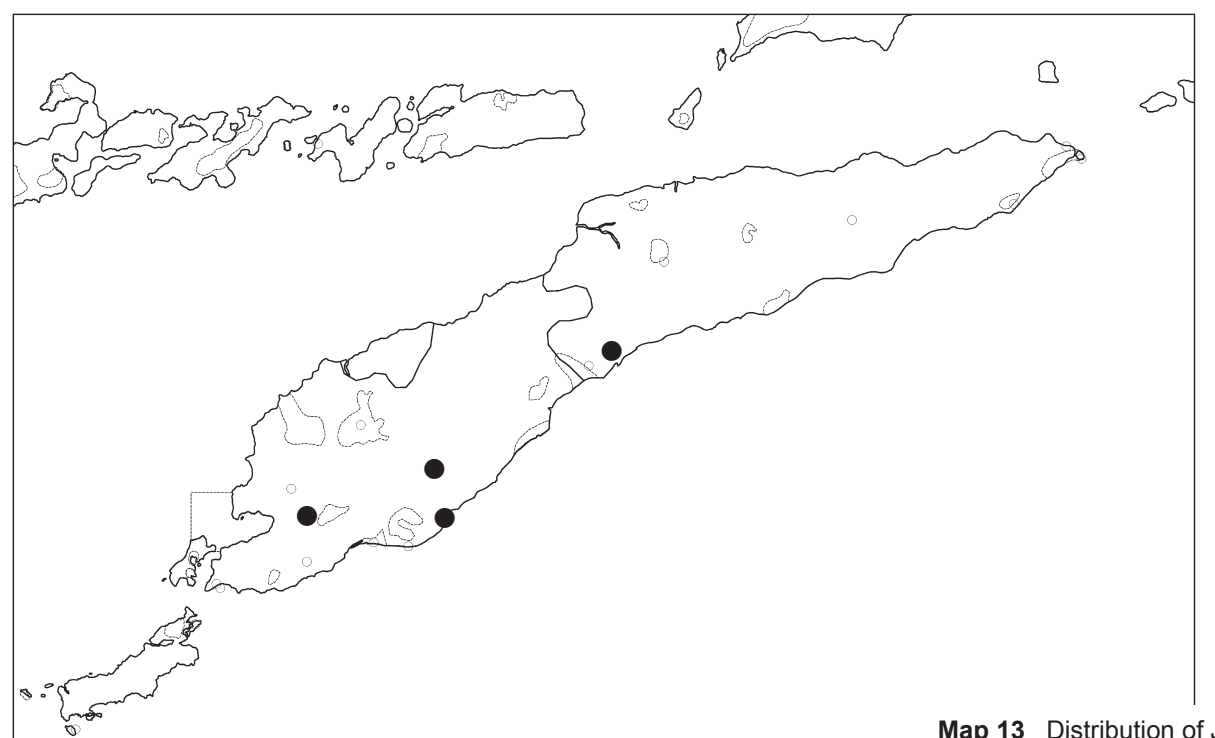

Map 13 Distribution of Jacquemontia paniculata (Burm.f.) Hallier $\mathrm{f}$. 
1. Stems and leaves sparsely pilose to glabrescent; inflorescences densely tomentose. Peduncles shorter, only to $5 \mathrm{~mm}$ long. Corolla white . . . . . . . . . . . var. jonkeri

\section{a. var. zollingeri}

Distribution - Malesia: East Java (Mt Baluran in Besuki), Lesser Sunda Islands (Bali, Sumbawa, Timor) (Van Ooststroom \& Hoogland 1953).

Habitat \& Ecology - In thickets, from sea level to c. $30 \mathrm{~m}$ (Van Ooststroom \& Hoogland 1953).

\section{b. var. jonkeri Ooststr}

Jacquemontia zollingeri var. jonkeri Ooststr. (1939) 276; Ooststr. (in Ooststr. \& Hoogland 1953) 433. - Type: Jonker 285 (U), Timor.

Distribution - Timor (Van Ooststroom \& Hoogland 1953).

10. MERREMIA Dennst. ex Endl. (1841) 1403, nom. cons.

\section{Key to the species of Merremia}

1. Leaves palmately compound, with 5 leaflets, or palmately $5-7$-lobed . . . . . . . . . . . . . . . . 2

1. Leaves entire or crenate to shallowly or deeply 3-lobed . 3

2. Leaves palmately compound. Leaflets 5 , entire, linear, lanceolate or narrowly oblong. Sepals $7.5-13 \mathrm{~mm}$ long, without glandular pellucid dots. Corolla white or pale pink, glabrous outside . . . . . . . . . . . . . . . . . 5. M. quinata

2. Leaves palmately lobed. Lobes $5-7$, broad triangular to lanceolate. Sepals $12-20 \mathrm{~mm}$ long, with glandular pellucid dots. Corolla bright yellow, with distinctly 5 -nerved midpetaline bands .................... . . . vitifolia

3. Peduncles very short or nearly absent. Sepals all more or less hairy on the back and long ciliate at the margins. Leaves reniform to broadly ovate ........... 2. M. emarginata

3. Peduncles $1-10 \mathrm{~cm}$ (rarely up to $16 \mathrm{~cm}$ ). Sepals glabrous or occasionally slightly pilose on the back and along the margins. Leaves not reniform to broadly ovate . . . . . . 4

4. Corolla with midpetaline bands pilose only at their top, 20-30 $(-35) \mathrm{mm}$ long. Stems terete or slightly striate.... . . . . . . . . . . . . . 6. M. umbellata subsp. orientalis

4. Corolla entirely glabrous outside, up to $20 \mathrm{~mm}$ long. Stems slender, smooth or minutely tuberculate . . . . . . 5

5. Bracts persistent. Corolla white ... . . . 1. M. dichotoma

5. Bracts caducous. Corolla yellow . . . . . . . . . 6
6. Corolla up to $12 \mathrm{~mm}$ long. Sepals with a distinct mucro, directed outwards ............... 4. M. hederacea

6. Corolla $15-20 \mathrm{~mm}$ long. Sepals not or slightly mucronulate, in which case mucro not directed outwards. 3. M. gemella

\section{Merremia dichotoma Ooststr. - Map 14}

Merremia dichotoma Ooststr. (1939) 311; Ooststr. (in Ooststr. \& Hoogland 1953) 443; Kalkman (1955) 216. - Type: Walsh 375 (holo BO n.v.; iso BM), Indonesia, Kolbano, 30.iv.1929.

Distribution - Timor (Van Ooststroom \& Hoogland 1953).

Habitat \& Ecology - Climber. One specimen was collected by the coast (Walsh 375), the other at a mountain site (Kooy 794).

Vernacular name - Knâtan (Timor: dialect unknown) (Van Ooststroom \& Hoogland 1953).

Note - Van Ooststroom (Van Ooststroom \& Hoogland 1953) first described $M$. dichotoma as having a white corolla. According to Kooy's collection notes (Kooy 794), the specimen from Timor had a yellow corolla. Since the type specimen Walsh 375 does not have any indication about the colour of the corolla, it is possible that Van Ooststroom speculated that it was white, from the analysis of the preserved Walsh's specimen. Van Ooststroom may have made a wrong assumption or the species may indeed exhibit some variability in corolla colour.

\section{Merremia emarginata (Burm.f.) Hallier f. - Map 14}

Merremia emarginata (Burm.f.) Hallier f. (1893a) 552; Ooststr. (in Ooststr. \& Hoogland 1953) 444; Kalkman (1955) 216

Evolvulus emarginatus Burm.f. (1768) 77.

Ipomoea reniformis Choisy (1834) 446; Decne. (1834) 396; Span. (1841) 338; Fawc. (1885) 511

Lepistemon reniformis (Roxb.) Hassk. (1848) 524; Miq. (1856) 629.

Distribution - Tropical Africa, tropical Asia, in Malesia: Java, Southeast Borneo, Celebes (Donggala, Pasui), Lesser Sunda Islands (Timor, Sumbawa), and Philippines (Luzon) (Van Ooststroom \& Hoogland 1953).

Habitat \& Ecology — On rather heavy soils, in fields and open grasslands, along railroads and in waste places; restricted to regions with a rather strong to very strong dry season; from sea level to $200 \mathrm{~m}$ (Van Ooststroom \& Hoogland 1953).

Uses - In the Philippines the leaves and tops in decoction are sometimes used as a diuretic and in Java for coughs (Van Ooststroom \& Hoogland 1953).

Vernacular name - Naof luken (Dawan).

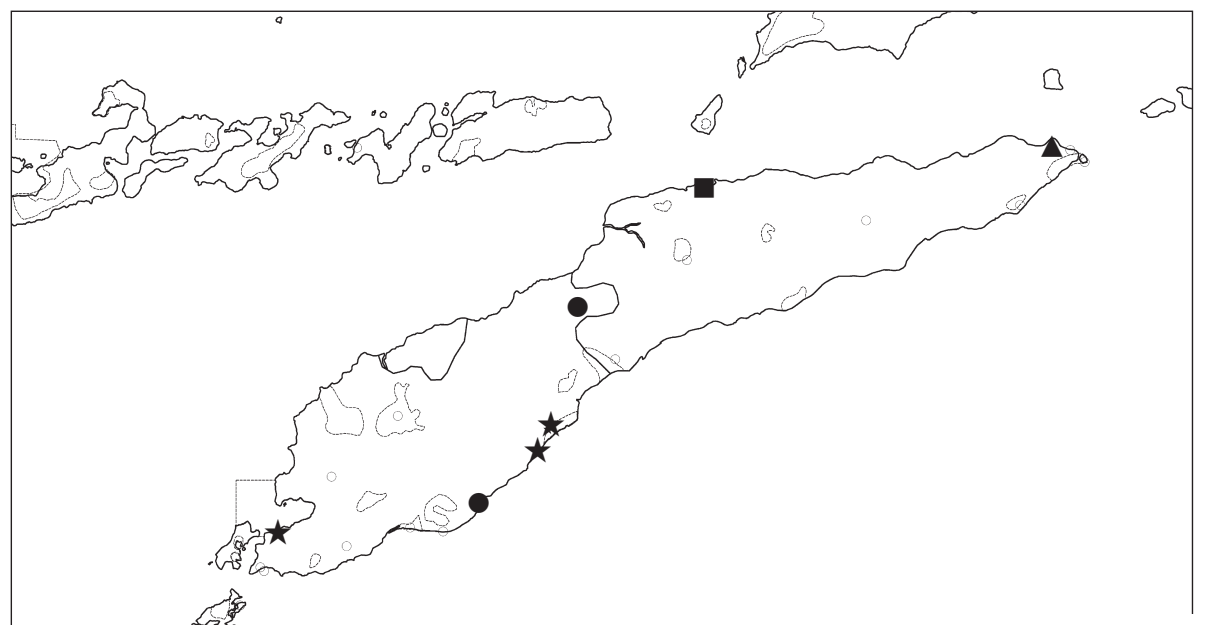

Map 14 Distribution of Merremia dichotoma Ooststr. (๑), M. emarginata (Burm.f.) Hallier f. ( $\star$ ), M. gemella (Burm.f.) Hallier f. (A) and M. hederacea (Burm.f.) Hallier f. (ם) 


\section{Merremia gemella (Burm.f.) Hallier f. - Map 14}

Merremia gemella (Burm.f.) Hallier f. (1893a) 552; Ooststr. (in Ooststr. \& Hoogland 1953) 441.

Convolvulus gemellus Burm.f. (1768) 46.

Distribution - Southeast Asia to tropical Australia, throughout Malesia (Van Ooststroom \& Hoogland 1953).

Habitat \& Ecology — In thickets, on hedges, in grasslands, in teak-forests, along railroads, on dikes of rice-fields, often on moist soil, from sea level to $250 \mathrm{~m}$ (Van Ooststroom \& Hoogland 1953). The specimen seen from East Timor was collected at $400 \mathrm{~m}$.

\section{Merremia hederacea (Burm.f.) Hallier f. — Map 14}

Merremia hederacea Hallier f. (1893b) 118; Ooststr. (in Ooststr. \& Hoogland 1953) 441; Kalkman (1955) 216.

Evolvulus hederaceus Burm.f. (1768) 77

Ipomoea chryseides Ker Gawl. (1818) t. 270; Decne. (1834) 392; Span. (1841) 339; Miq. (1856) 616; Fawc. (1885) 511.

Distribution - Tropical Africa, Mascarene Islands, tropical Asia from the Himalaya southwards to Sri Lanka and eastwards to Myanmar, Southern China, Indo-China, and Siam (Thailand), to Queensland, and the Carolines (Yap), throughout Malesia, also in Christmas Island (Van Ooststroom \& Hoogland 1953).

Habitat \& Ecology - In thickets, in open grasslands, and on sand-banks, from sea level to $50 \mathrm{~m}$ (Van Ooststroom \& Hoogland 1953).

Uses - Used for treating acute tonsillitis (Fang \& Staples 1995); a poultice of the leaves, with turmeric and broken rice, is used upon chapped hands and feet. Animals eat the plant (Burkill in Van Ooststroom \& Hoogland 1953).

Vernacular name - Ai-talic (Tetum).

\section{Merremia quinata (R.Br.) Ooststr. - Map 15}

Merremia quinata (R.Br.) Ooststr. (in Ooststr. \& Hoogland 1953) 447. Ipomoea quinata R.Br. (1810) 486.

Distribution - Myanmar, Thailand, China, Indonesia, Philippines, New Guinea, North Australia (Fang \& Staples 1995). New record for Timor.

Habitat \& Ecology - In open mountain slopes (Fang \& Staples 1995).

\section{Merremia umbellata (L.) Hallier f.}

Merremia umbellata (L.) Hallier f. (1893a) 552; Kalkman (1955) 216. Convolvulus umbellatus L. (1753) 155.

Ipomoea cymosa Roem. \& Schult. (1819) 241; Decne. (1834) 392; Miq. (1856) 613; Span. (1841) 339; Fawc. (1885) 511.

a. subsp. orientalis (Hallier f.) Ooststr. - Map 15

Merremia umbellata subsp. orientalis (Hallier f.) Ooststr. (in Ooststr. \& Hoogland 1953) 449.

Merremia umbellata var. orientalis Hallier f. (1895) 132.

Distribution - Tropical East Africa, Seychelles, Sri Lanka, India, Nepal, China, Bangladesh(?), Myanmar, Cambodia, Laos, Vietnam, Malaysia, Indonesia, East Timor, New Guinea, Philippines and North Australia (Van Ooststroom \& Hoogland 1953, Fang \& Staples 1995).

Habitat \& Ecology - In thickets, along edges of forests, in grasslands, along fields, along waysides, from sea level to c. 1100 m (Van Ooststroom \& Hoogland 1953).

Uses - Used in China (Guangxi) for treating infections (Fang \& Staples 1995); the pounded leaves may be used as a poultice for burns and scalds or for sores, as in the Moluccas; the young leaves may be mixed with vegetables and eaten (Burkill, Heyne in Van Ooststroom \& Hoogland 1953).

\section{Merremia vitifolia (Burm.f.) Hallier f. - Map 15}

Merremia vitifolia (Burm.f.) Hallier f. (1893a) 552; Ooststr. (in Ooststr. \& Hoogland 1953) 448; Kalkman (1955) 216.

Convolvulus vitifolius Burm.f. (1768) 45, pl. 18, f. 1

Ipomoea vitifolia (Burm.f.) Sweet (1826) 289; Decne. (1834) 391; Span. (1841) 339; Miq. (1856) 607; Fawc. (1885) 511.

Distribution — India, Sri Lanka, Nepal, Myanmar, Thailand, Laos, Vietnam, Indonesia, Malaysia; throughout Malesia (Van Ooststroom \& Hoogland 1953, Fang \& Staples 1995).

Habitat \& Ecology — In open grasslands, thickets, hedges, along fields, in teak-forests, along edges of secondary forests, on river-banks and waysides; both in regions with a feeble and rather strong dry season; from sea level to c. $900 \mathrm{~m}$ (Van Ooststroom \& Hoogland 1953). Not very frequent in Timor.

Uses - Used for treating bladder infections, stomach aches (Fang \& Staples 1995), for poulticing and for treating high fever, for which an infusion of the plant is drunk (Burkill in Van Ooststroom \& Hoogland 1953).

Vernacular name - Tcha-tchumaco (Timor: unknown dialect).

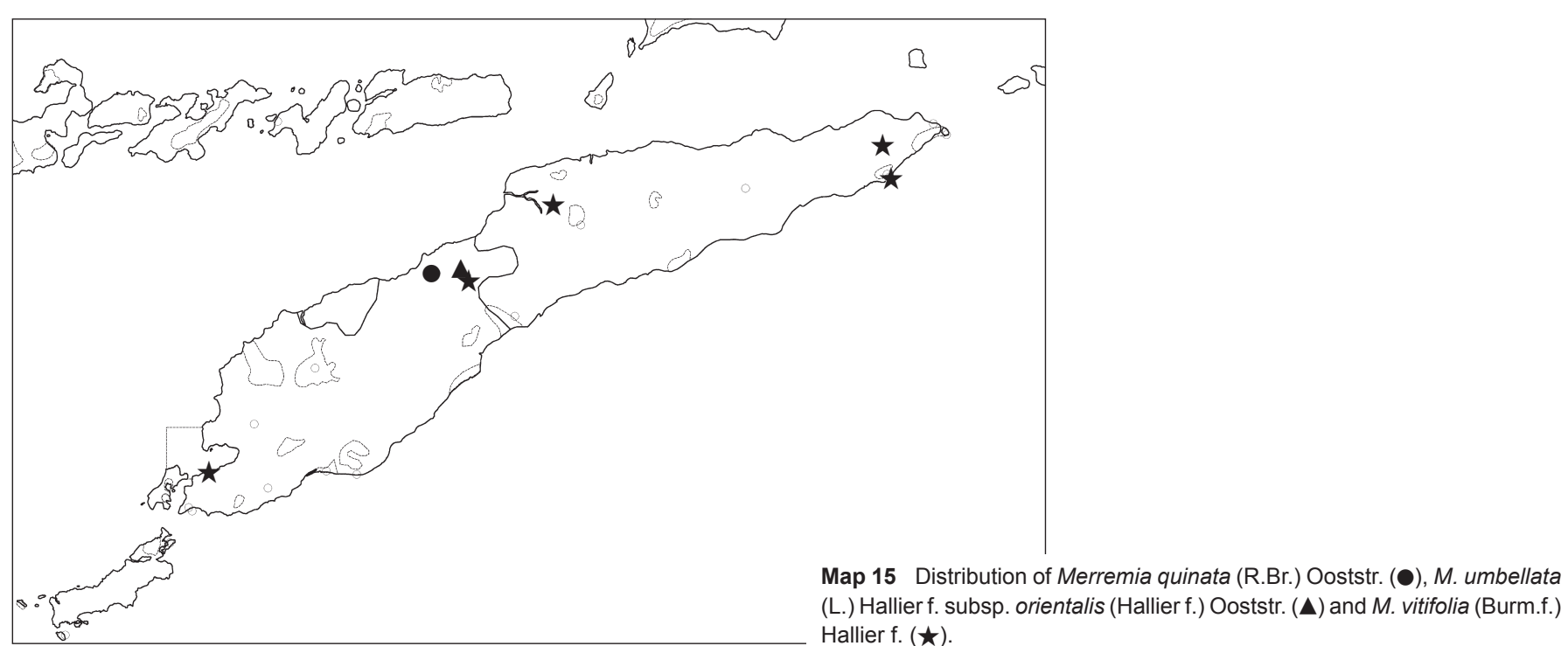




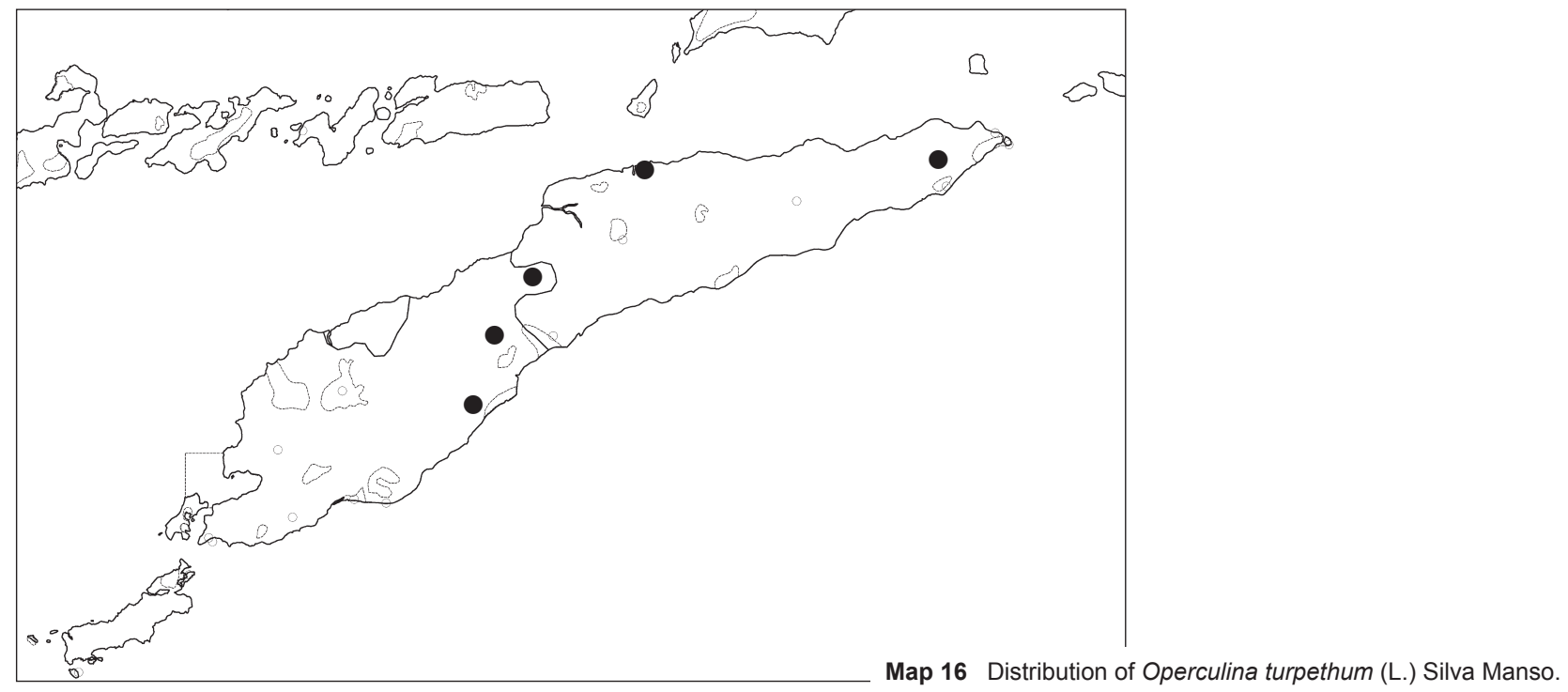

\section{OPERCULINA Silva Manso (1836) 49}

\section{Key to the species of Operculina}

1. Stems terete. Corolla with midpetaline bands densely sericeous-pilose outside; pale yellow or rarely white. Seeds with 2 pilose-papillose edges ........... 1. O. riedeliana

1. Stems narrowly 3-5-winged, sulcate or angular. Corolla glabrous or with minute yellowish glands outside; entirely white or white with yellowish base. Seeds glabrous ..... $\ldots \ldots \ldots \ldots \ldots \ldots \ldots \ldots \ldots$ 2. O. turpethum

\section{Operculina riedeliana (Oliv.) Ooststr.}

Operculina riedeliana (Oliv.) Ooststr. (1939) 366; Ooststr. (in Ooststr. \& Hoogland 1953) 457; Kalkman (1955) 216.

Ipomoea riedeliana Oliv. (1883) t. 1424

Ipomoea petaloidea auct. non Choisy (1834) 451; Decne. (1834) 64; Span.

(1841) 339; Miq. (1856) 606; Fawc. (1885) 511.

Distribution - Andaman Islands, extreme southern Thailand, throughout Malesia and New Guinea (Staples 2007).

Habitat \& Ecology - In thickets, edges of secondary forests and hedges; at low altitudes (Van Ooststroom \& Hoogland 1953).

\section{Operculina turpethum (L.) Silva Manso - Map 16}

Operculina turpethum (L.) Silva Manso (1836) 49; Ooststr. (in Ooststr. \& Hoogland 1953) 456; Kalkman (1955) 216

Convolvulus turpethum L. (1753) 155.

Ipomoea turpethum (L.) R.Br. (1810) 485; Decne. (1834) 390; Span. (1841) 338.

Distribution - Tropical East Africa, Mascarenes, Seychelles; South and Southeast Asia to tropical Australia and Polynesia; throughout Malesia (Van Ooststroom \& Hoogland 1953). Introduced and naturalized in the West Indies (Staples \& Austin 1981).

Habitat \& Ecology — In thin forests, thickets, teak-forests, hedges, along fields, waysides, waste places, occasionally in sugar-plantations; restricted to regions with a medium or strong east monsoon; from sea level to c. $1300 \mathrm{~m}$ (Van Ooststroom $\&$ Hoogland 1953). Not very common in Timor.

Uses - Extracts of $O$. turpethum are used for two main purposes: as a purgative to reduce or balance humours and to reduce fevers. Also, intestinal worms of various kinds are expelled by the laxative effects of the medicine made from this plant (Austin 1982). The active principles of the medicine are apparently concentrated in the bark of the roots, of which two types might be produced: white roots that are mild, and black roots that give drastic, often poisonous effects (Watt in Austin

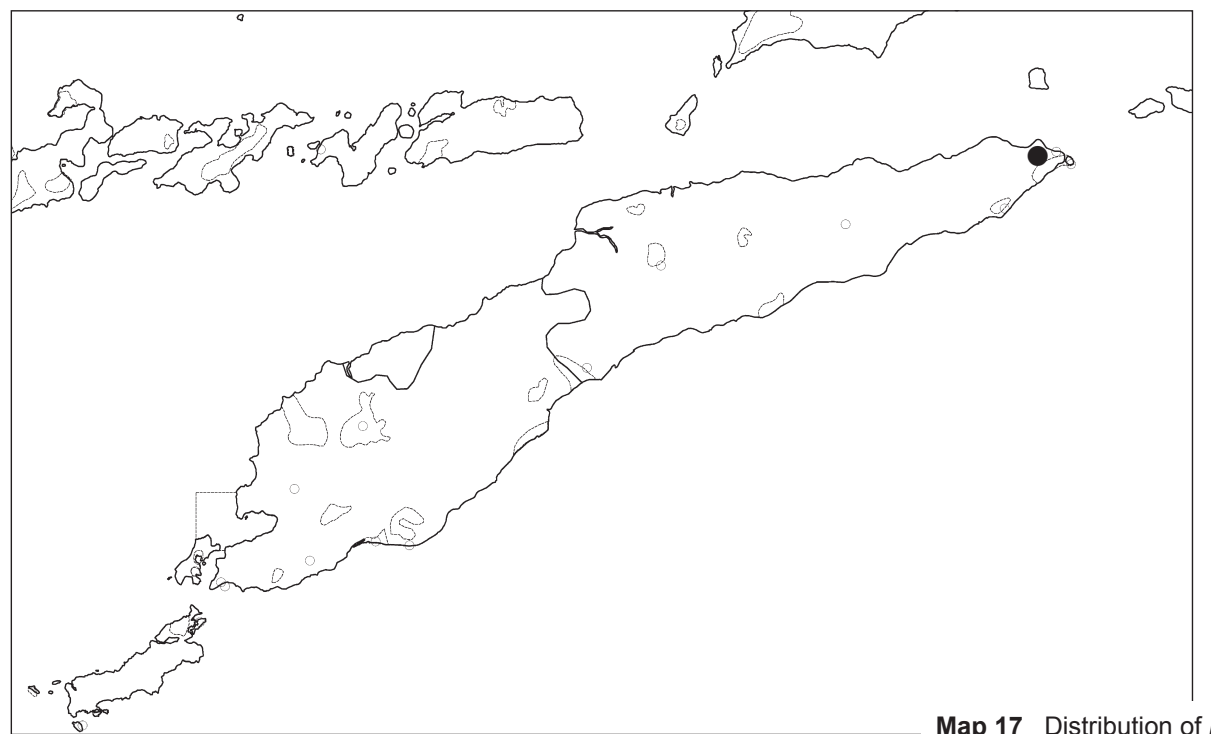


1982). Also, the stems have been reported to be used for tying in the Philippines (Van Ooststroom \& Hoogland 1953).

Vernacular names — Lak-laku (Dawan); non-loli (Timor: unknown dialect); tali anduk (Tetum).

\section{POLYMERIA R.Br. (1810) 488}

\section{Polymeria pusilla R.Br. - Map 17}

Polymeria pusilla R.Br. (1810) 488; Ooststr. (1958) 559.

Distribution - Australia (Queensland), New Caledonia; Timor (Van Ooststroom 1958).

Habitat \& Ecology — In pyrogenous grassland on the Fuiloro plateau, at $400 \mathrm{~m}$ (Van Ooststroom 1958).

Note - This small prostrate plant shows an interesting pattern of distribution. Although sometimes taken for an Australian endemic (Stefanovic et al. 2003), it was actually collected in Timor as well, and in a rather remote location. It might be that the species occurs in Timor due to the proximity with the Australian coast, and is yet restricted to this rather small distribution range. However, the species may be more widespread: as Heine (1984) suggested, its small habit means that it is not easily recognized in the field.

\section{PORANA Burm.f. (1768) 51 , t. $21^{*}$, f. 1}

\section{Porana volubilis Burm.f. - Map 18}

Porana volubilis Burm.f. (1768) 51, t. 21*, f. 1; Decne. (1834) 394; Span. (1841) 341; Miq. (1856) 625; Fawc. (1885) 511; Ooststr. (in Ooststr. \& Hoogland 1953) 402; Kalkman (1955) 216. - Porana volubilis Burm.f. var. burmanniana Blume (1826) 723. - Type: Zippelius 91 (lecto L).

Porana volubilis Burm.f. var. microcarpa Engl. (1866) 472. - Type: Naumann s.n. (holo B n.v., presumed destroyed).

Distribution - Southern India, Myanmar, Thailand, Laos, Cambodia, Vietnam, Malaysia, Indonesia, East Timor and the Philippines (Van Ooststroom \& Hoogland 1953, Staples 2006).

Habitat \& Ecology - Thickets, edges of forests, teak forests, from sea level to c. $200 \mathrm{~m}$, sometimes higher. In Timor, up to 750 m (Van Ooststroom \& Hoogland 1953).

Vernacular names - Cidani (Tetum); nuit (or nüif) (Timor: unknown dialect).

Uses - A decoction of the plant is used in stimulating the afterbirth (Van Ooststroom \& Hoogland 1953). Both leaves and flowers are edible; the leaves can be eaten to remove an unpleasant taste from the mouth. The plant is cultivated in the gardens for ornamental purposes (Van Ooststroom \& Hoogland 1953); the flowers are appreciated for their delicate fragrance (Staples 2006).

\section{STICTOCARDIA Hallier f. (1893b) 159}

Note - There seems to be a remarkable incidence of species from the genus Stictocardia in the Lesser Sunda Islands. Out of the 11 species known to occur in tropical Africa and Asia (Austin \& Eich 2001), four occur in Malesia (S. cordatosepala, S. discolor, S. neglecta, S. tiliifolia), and apart from the widespread S. tiliifolia, all are exclusive to the Lesser Sunda Islands, while one species is endemic to Timor ( $S$. discolor) (Van Ooststroom \& Hoogland 1953). Also, there is a Northeastern Australian endemic - S. queenslandica (Domin) R.W. Johnson, which apparently is rather similar to $S$. discolor. Both species differ from $S$. tiliifolia by their shorter sepals and corollas. However, $S$. discolor apparently has more slender peduncles and pedicels than the Australian endemic, and $S$. queenslandica does not have the extraordinary red colouration on the abaxial surface of the leaves that always occurs in S. discolor (and occasionally in S. neglecta) (Johnson 2004). Overall, it seems that the Australasian region is an important centre of species richness of Stictocardia, which would be interesting to investigate in the context of the evolution of the genus.

\section{Key to the species of Stictocardia}

1. Sepals at anthesis $12 \mathrm{~mm}$ or more long. Corolla $8-10 \mathrm{~cm}$ long. Leaves up to $20 \mathrm{~cm}$ wide. Abaxial surface of the leaves always green ... . . . . . . . . . . . 3. S. tiliifolia

1. Sepals at anthesis less than $12 \mathrm{~mm}$ long. Corolla less than $8 \mathrm{~cm}$ long. Leaves up to $7.5 \mathrm{~cm}$ wide. Abaxial surface of the leaves green or reddish . . . . . . . . . . . 2

2. Stems, leaves and inflorescences very sparsely pubescent or glabrous. Leaves with long and narrow, obtuse or acutish, mucronulate acumen. Sepals shortly ciliate in the upper part. Abaxial surface of the leaves always reddish 1. S. discolor

2. Stems leaves and inflorescences densely pubescent to tomentose. Leaves attenuate to slightly acuminate towards the apex. Sepals not ciliate. Abaxial surface of the leaves green or sometimes reddish . . . . . . 2. S. neglecta

\section{Stictocardia discolor Ooststr. - Map 19}

Stictocardia discolor Ooststr. (1943) 350; Ooststr. (in Ooststr. \& Hoogland 1953) 493; Kalkman (1955) 216. - Type: Reinwardt 1350 (L!), Timor.

Distribution - Timor (Van Ooststroom \& Hoogland 1953). Vernacular name — Lak-laku mè (Dawan).

Note - The red colouration on the lower surface of the leaves sets this species apart from the pantropical $S$. tiliifolia. However, this character may also occur in S. neglecta (Van Ooststroom \& Hoogland 1953).

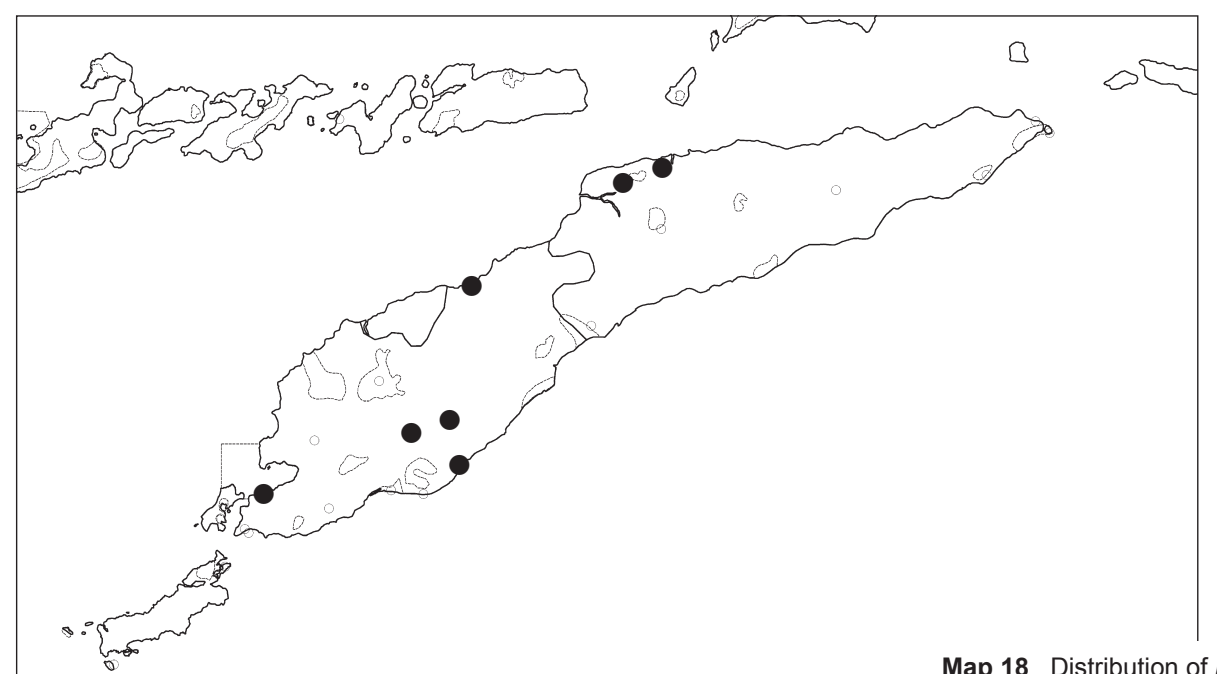




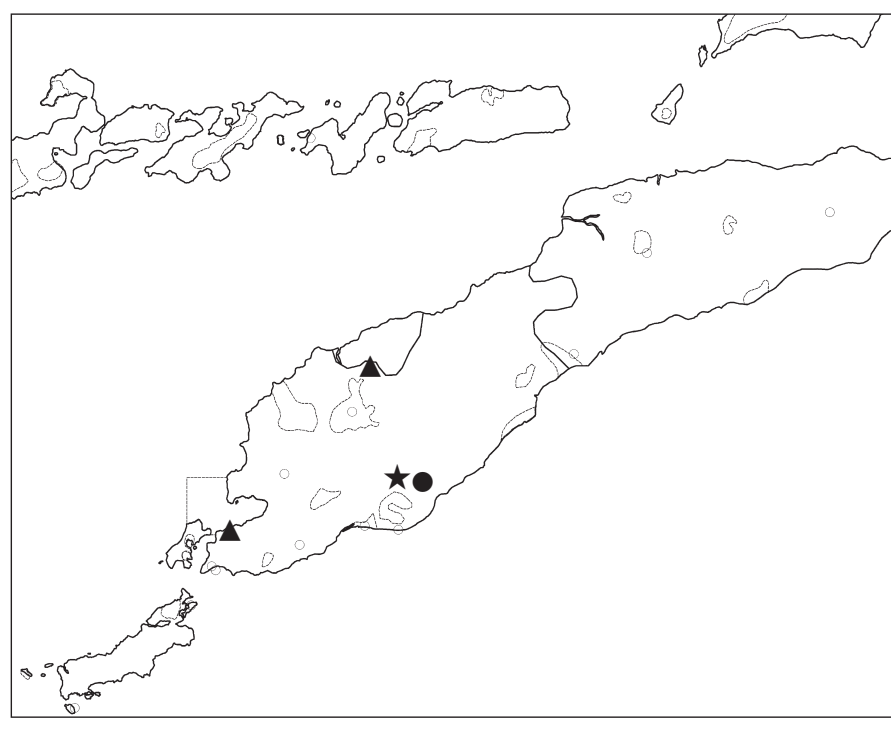

\section{Stictocardia neglecta Ooststr. - Map 19}

Stictocardia neglecta Ooststr. (1943) 348; Ooststr. (in Ooststr. \& Hoogland 1953) 491; Kalkman (1955) 216. - Syntypes: Walsh 373 (BM, BO), Indonesia (West Timor), Ofu, c. 305 (900?) m, 2.v.1929; Teysmann s.n. (BO), Indonesia (West Timor), Kupang

Distribution - Malesia: Southwest Celebes, Lesser Sunda Islands (Timor, Wetar) (Van Ooststroom \& Hoogland 1953).

Habitat \& Ecology - Creeper. In thickets up to c. $900 \mathrm{~m}$ (Van Ooststroom \& Hoogland 1953). According to Walsh (specimen Walsh 373, BM), the plant was common throughout Timor at the date of collection, 1929; sadly, more recent reliable data are not available to inform on the present abundance of the species in the island.

Vernacular names — Lololi; non laku; non loli (Timor: unknown dialect); sekal zon (Bunaq).

\section{Stictocardia tiliifolia (Desr.) Hallier f. - Map 19}

Stictocardia tiliifolia (Desr.) Hallier f. (1893b) 159 ('tiliaefolia'); Ooststr. (in Ooststr. \& Hoogland 1953) 491

Convolvulus tiliifolius Desr. (1792) 544.

Ipomoea grandiflora (L.f.) Lam. (1792) 467; Fawc. (1885) 511.

Ipomoea pulchra Blume (1826) 716; Span. (1841) 340.

Distribution - Circumtropical, throughout Malesia (Van Ooststroom \& Hoogland 1953).

Habitat \& Ecology - On and behind seashore, sometimes also in the interior; in thickets, hedges and secondary forests; up to c. 900 m (Van Ooststroom \& Hoogland 1953).

Vernacular name - Faif foro (Timor: unknown dialect).

\section{XENOSTEGIA D.F.Austin \& Staples (1980) 533}

\section{Xenostegia tridentata (L.) D.F.Austin \& Staples - Map 20}

Xenostegia tridentata (L.) D.F.Austin \& Staples (1980) 533.

Convolvulus tridentatus L. (1753) 157.

Ipomoea angustifolia Jacq. (1788) 367; Fawc. (1885) 511

Convolvulus hastatus Desr. in Lam. (1792) 542.

Ipomoea filicaulis Blume (1826) 721; Decne. (1834) 390; Span. (1841) 338; Miq. (1856) 603.

Merremia tridentata (L.) Hallier f. (1893a) 552; Ooststr. (in Ooststr. \& Hoogland 1953) 445; Kalkman (1955) 216.

Merremia tridentata (L.) Hallier f. subsp. hastata (Desr.) Ooststr. (1939) 317. Merremia tridentata (L.) Hallier f. subsp. angustifolia (Jacq.) Ooststr. (1939) 323.

Distribution - Bangladesh (?), Cambodia, India, Indonesia, Laos, Malaysia, Myanmar, New Guinea, Philippines, Singapore,
Sri Lanka, Thailand, Vietnam; Africa, North Australia (Fang \& Staples 1995). Also in East Timor.

Habitat \& Ecology - Winding in grass; in sandy places near the coast (Van Ooststroom \& Hoogland 1953).

Uses - The leaf is made into poultice and applied to the head in cases of jungle-fever in Peninsular Malaysia (Van Ooststroom \& Hoogland 1953).

Note - Van Ooststroom (Van Ooststroom \& Hoogland 1953) proposed several subspecies within Merremia tridentata (L.) Hallier $f$. Because of the obvious intergradation between the characters, our view is that there are no adequate differences to recognise the three subspecies and they should be treated as one single taxon (Xenostegia tridentata). It is notable that the specimens we have seen from Timor all seem to fit the description of Merremia tridentata subsp. hastata, which agrees with Van Ooststroom's notes on the distribution of the subspecies. Van Ooststroom does not report subsp. tridentata from Timor, and no distribution notes are indicated for subsp. angustifolia, but synonyms of subsp. angustifolia (Ipomoea angustifolia Jacq., Ipomoea filicaulis Blume) have been reported to occur in Timor (Decaisne 1834, Spanoghe 1841, Fawcett 1885).

\section{ETHNOBOTANICAL NOTES}

Convolvulaceae seem to be widely used in the island of Timor, and a significant number of species was found to have ethnobotanical value not only in Timor but also across its distribution range. Twenty-one taxa of Convolvulaceae are known to have medicinal use; seven can be used as food; four are used for ornamental purposes and three have other various applications. Argyreia paivae, described in this paper and which appears to be endemic to Timor, is used medicinally for treating gonorrhoea. Apart from the pharmacological interest, it is noteworthy that there is a vernacular name for this species, so the plant is familiar to local people. Such information could be useful for motivating the local communities to get involved in future conservation strategies, focussing on this and other species that are useful to them.

A great part of the listed taxa with known uses has been reported to East Timor, meaning that they might hold potential for sustainable economical use (e.g. in pharmaceutical research or agro-alimentar industry) in alternative to other damaged or depleted natural resources of the territory. 


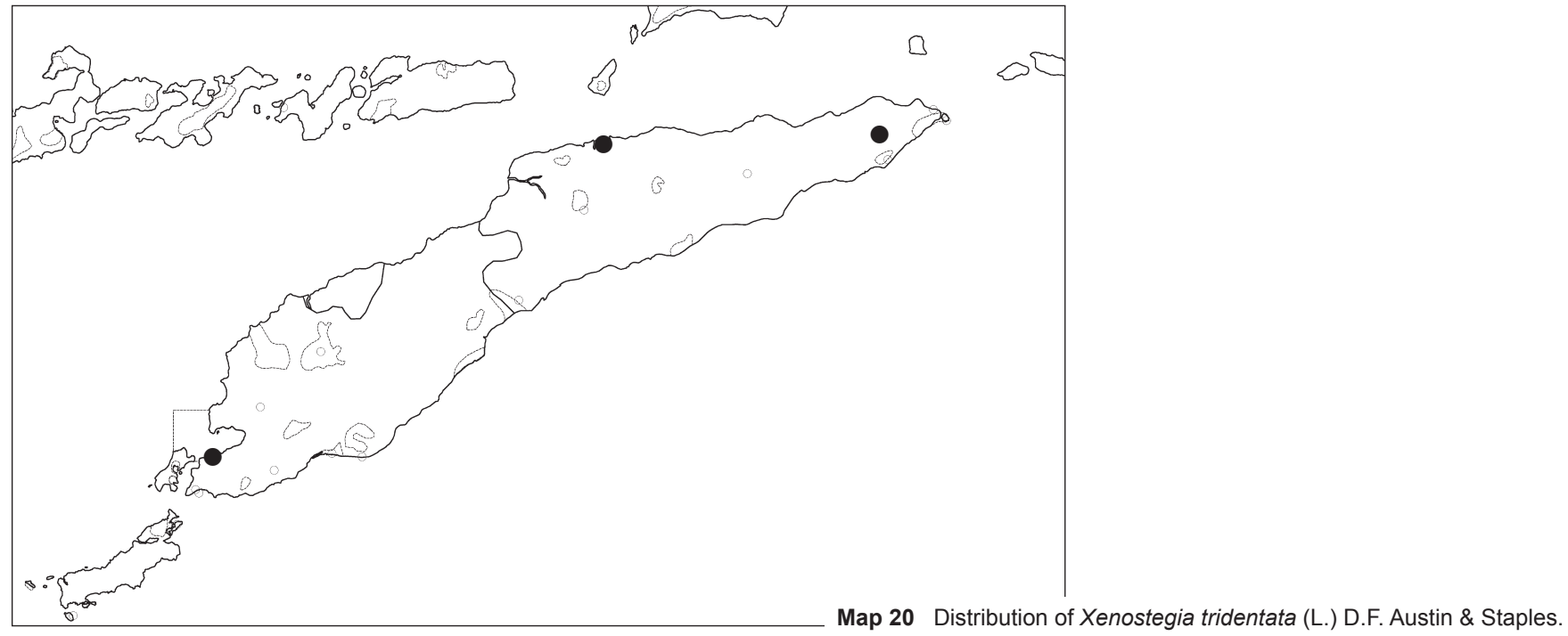

\section{CONSERVATION NOTES}

There are currently 17 recognized protected areas in East Timor, 16 of which were designated during the United Nations temporary government of the territory, in 2000 (IUCN \& UNEP 2007). Most of these areas are little studied and, given that the plant diversity of East Timor has not been accurately assessed yet, the protected areas are probably not sufficient to protect the endemic, endangered and vulnerable species of East Timor.

The Nino Konis Santana National Park was created in 2007 and covers 123600 ha (Map 21) at the eastern tip of East Timor. It was designated to protect a number of Critically Endangered and Endangered bird species. However, it is a great contribution to the protection of species from other groups, and a sign that Timorese communities and Government are willing to collaborate to protect and manage their natural resources in a sustainable way (Birdlife International 2008).

None of the six species of Convolvulaceae currently considered endemic to Timor are endemic to East Timor. Also, considering the scarceness of specimens available from Timor, the validity of the endemic species is likely to need to be re-assessed, as soon as more collections are made in the island and its surroundings.

It is noteworthy that most Convolvulaceae specimens from Timor were collected outside designated protected areas. This may reflect the limited knowledge of the flora of protected areas in Timor and we suggest that these sites would be better collected.

However, we would also suggest that the conservation status of sites, such as Tatamailau hillsides, Fuiloro plateau or the surroundings of the Lore reserve, where endemic Convolvulaceae have been collected, should be the focus of further study as they are likely to have an interesting unique flora.

None of the species of Convolvulaceae in Timor are listed in CITES or IUCN as needing special protection measures. However, accurate evaluations on the conservation status of species from the island of Timor have not yet been attempted and in the current study, it was not possible to assess such conservation status because vital information was missing, such as precise collection sites, size of populations or real distribution ranges. Although we have reached no definite conclusion in this study, it is expected that the data provided would be a useful source for further studies on conservation status of Convolvulaceae in Timor.

The lack of botanical data has been a great constraint for the establishment of more protected areas and for the assessment of conservation status of species in East Timor. A comprehensive assessment of the botanical resources of the island is required, with greater effort in East Timor. Compiling all the available botanical data and including them in conservation programmes would provide a much more powerful tool in the management of the local natural resources.
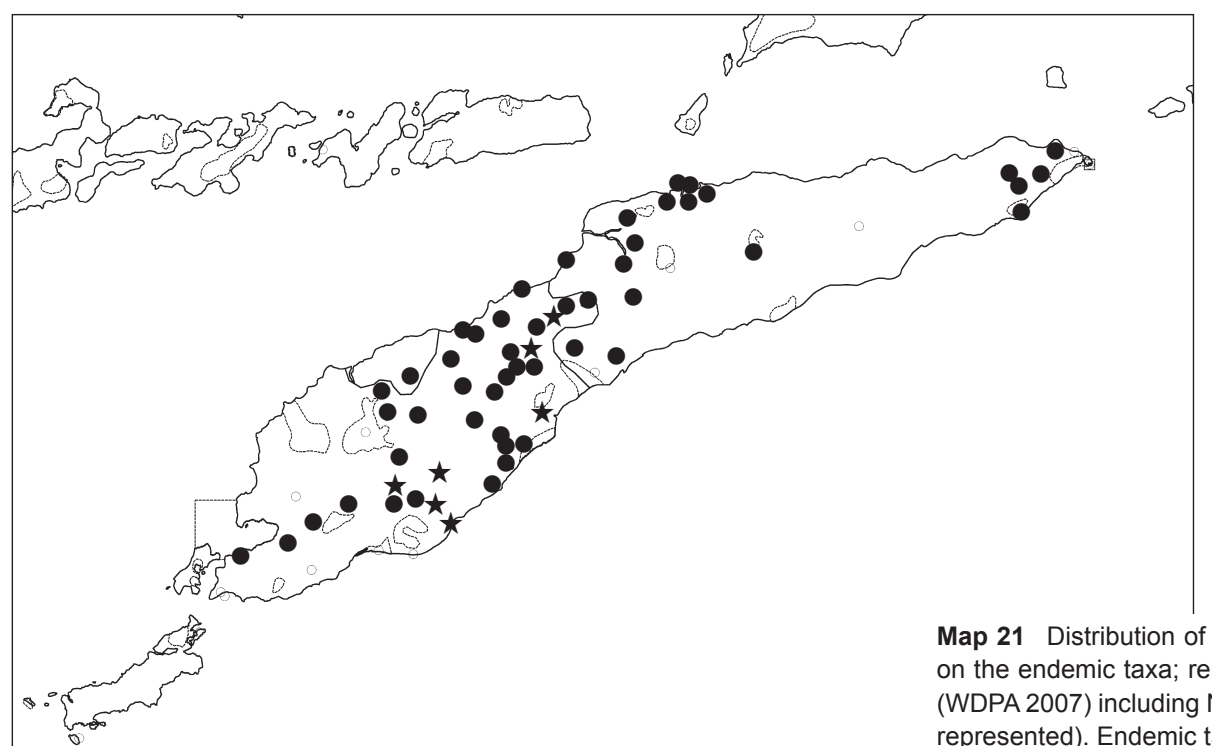

Map 21 Distribution of all Convolvulaceae from Timor, with special focus on the endemic taxa; representation of all the designated protected areas (WDPA 2007) including Nino Konis National Park (real limits of the park not represented). Endemic taxa $(\star)$, remaining taxa $(\bullet)$. 


\section{CONCLUSION}

In Timor, we find a total of 61 different taxa of Convolvulaceae. Fifty three species are recognised in 15 different genera. Eight of the species have a circumtropical distribution, whereas six appear to be endemic to the island of Timor. The rest of the species have shown a larger distribution in Malesia, or expanded to tropical Africa and/or America.

Ten nomenclatural changes to Flora Malesiana's taxonomic treatment were adopted in this checklist. A few taxonomic issues remain to be resolved, namely in Jacquemontia paniculata and Xenostegia tridentata, where further studies should be carried out.

The recent collection efforts in the island (2004 and 2005) resulted in a new species record to East Timor (Cuscuta campestris) and to the island. Examination of herbarium material also resulted in another new record to Timor, Merremia quinata, and a newly described taxon, Argyreia paivae, which is most likely endemic to Timor, and holds potential to be used as a medicinal plant.

The need to assess the botanical resources of the island, with special focus on protected areas and sites where endemics have been reported is highlighted. It is hoped that the compilation of ethnobotanical data in this paper will assist the local population by providing a tool to facilitate the production of non-scientifically oriented publications, such as field guides or ethnobotanical leaflets or books. This paper, together with that of Silveira et al. (2008), provides a starting point for further botanical research in the territory, to establish a more thorough understanding of the country's natural potential.

Acknowledgements The authors would like to thank Daniel Austin, George Staples, Jorge Paiva, and Thierry Deroin for specialized scientific advice. Also, Mark Carine for useful comments on the manuscript, Elske Kopenaal for help on the translation of herbarium labels in Dutch, Melanie Thomas who kindly revised the Latin diagnosis of the new species and António P. Coutinho who helped with the description of pollen characters. Collaboration of staff from BM, K, L, LISC and P in loans of specimens and personal visits to herbaria and libraries was much appreciated. This study would not have been possible without the financial support of Fundação Oriente and Fundação para a Ciência e Tecnologia (project POCTI/MGS/46905/2002), to which the authors are also thankful.

\section{REFERENCES}

Acevedo-Rodríguez P. 2003. Bejucos y plantas trepadoras de Puerto Rico e Islas Virgines. Smithsonian Institution, Washington, DC.

Andersen S. 1960. Silicon oil as a mounting medium for pollen grains. Danmarks Geologiske Undersogelse 4: 116-140.

Austin DF. 1977. Ipomoea carnea Jacq. vs. Ipomoea fistulosa Mart. ex Choisy. Taxon 26: 235-238.

Austin DF. 1982. Operculina turpethum (Convolvulaceae) as a medicinal plant in Asia. Economic Botany 36: 265-269.

Austin DF. 1986. Nomenclature of the Ipomoea nil complex (Convolvulaceae). Taxon 35: 355-358.

Austin DF. 2000. A revision of Cressa L. (Convolvulaceae). Botanical Journal of the Linnean Society 133: 27-39.

Austin DF. 2007. Water spinach (Ipomoea aquatica, Convolvulaceae): A food gone wild. Ethnobotany Research \& Applications 5: 123-146.

Austin DF. 2008. Evolvulus alsinoides (Convolvulaceae): An American herb in the Old World. Journal of Ethno-pharmacology 117: 185-198.

Austin DF, Eich E. 2001. Synopsis of Stictocardia with another Madasgacan species, S. mojangensis (Convolvulaceae). Willdenowia 31: 79-85.

Austin DF, Staples GW. 1980. Xenostegia, a new genus of Convolvulaceae. Brittonia 32: 533-536.

Birdlife International. 2008. Timor-Leste's first national park will protect the community's "wealth". http://www.birdlife.org/news/news/2008/09/timor_ reserve.html: accessed 25 Sept. 2008.

Blume CL. 1826. Bijdragen tot de flora van Nederlandsch Indië 13: 637-724. Lands Drukkerij, Batavia.

Brown R. 1810. Prodromus florae Novae Hollandiae. Taylor et socii, Londini.
Brown R inTuckey JK. 1816. Narrative of an expedition to explore the river Zaire, usually called the Congo, in South Africa, in 1816.

Burman NL. 1768. Flora Indica. Apud Cornelium Haek, Lugduni Batavorum.

Cavanilles AJ. 1795. Icones et descriptiones plantarum 3: 5. Typographia regia, Madrid.

Choisy JD. 1834 Convolvulaceae orientales. Mémoires de la Société de Physique et d'Histoire Naturelle de Genève 6: 383-502.

Choisy JD. 1845. Convolvulaceae. In: De Candolle AP (ed), Prodromus Systematis Naturalis Regni Vegetabilis 9: 323-461. Treuttel \& Wurtz, Paris.

De Loureiro J. 1790. Flora cochinchinensis. Typis, et expensis academicis, Ulyssipone.

Decaisne J. 1834. Herbarii Timorensis Descriptio. Nouvelles Annuales du Muséum d'Histoire Naturelle 3: 333-501.

Desrousseaux LAJ. 1792. In: Lamarck JBAP. Encyclopédie Méthodique. Botanique 3 (II): 438, 544. Panckoucke, Paris and Plomteux, Liège.

Delile AR. 1847. Index Seminum horti regii botanici monspelliensis anni 1847: 7 .

Don G. 1838. A general history of the Dichlamydeous plants 4: 1-908. J.G. \& F. Rivington et al., London.

Endlicher SFL. 1841. Genera plantarum 18: 1361-1483. Beck, Wien

Engelmann G. 1859. Systematic arrangement of the species of the genus Cuscuta. Transactions of the Academy of Science of Saint Louis 1: 513, 514.

Engler A. 1886. Die auf der Expedition S.M.S. "Gazelle" von Dr. Naumann im malayischen Gebiet gesammelten Siphonogamen (Phanerogamen). Botanische Jahrbücher für Systematik, Pflanzengeschichte und Pflanzengeographie 7: 472 .

Erdtman G. 1960. The acetolysis method, a revised description. Svensk Botanisk Tidskrift 54: 461-564.

Fang RC, Staples G. 1995. Convolvulaceae. In: Wu ZY, Raven PH (eds), Flora of China 16: 271-325. Science Press, Beijing and Missouri Botanical Garden, St. Louis.

Fawcett W. 1885. Gamopetale. In: Forbes HO (ed), A naturalist's wanderings in the eastern archipelago. Sampson Low, Marston, Searle \& Rivington, London.

Forsskål P. 1775. Flora Aegyptiaco-Arabica. Möller, Kjobenhavn.

Hallier HG. 1893a. Versuch einer natürlichen Gliederung der Convolvulaceen auf morphologischer und anatomischer Grundlage. Botanische Jahrbücher für Systematik, Pflanzengeschichte und Pflanzengeographie 16: 541, 543, 552.

Hallier HG. 1893b. Convolvulaceae africanae. Botanische Jahrbücher für Systematik, Pflanzengeschichte und Pflanzengeographie 18: 118, 159.

Hallier HG. 1895. Verslag omtrent den staat van 's Lands Plantentuin te Buitenzorg: 132. Botanical Garden Buitenzorg, Batavia.

Hasskarl JC. 1848. Plantae Javanicae Rariores Adjectis Nonnullis Exoticis, in Javae Hortis Cultis Descriptae, Berlin.

Hawthorne WD, Jongkind CCH. 2006. Woody plants of Western Africa. Royal Botanic Gardens, Kew.

Heine H. 1963. Convolvulaceae. In: Hepper FN (ed), Flora of West Tropical Africa. 2nd ed. 2: 335-352. Crown Agents for Oversea Governments and Administrations, London.

Heine H. 1984. Convolvulacées. In: Leroy J-F, Mackee HS (ed), Flore de la Nouvelle-Calédonie et Dépendances. Muséum national d'Histoire naturelle, Paris.

Heywood VH, Brummit RK, Culham A, Seberg O. 2007. Flowering plant families of the world. Royal Botanic Gardens, Kew.

Hoogland RD. 1953. Florae Malesianae Precursores II - The Convolvulaceae of Malaysia IX. Blumea 7: 318.

IUCN and UNEP. 2007. The World Database on Protected Areas (WDPA). UNEP-WCMC. Cambridge, UK. http://www.wdpa.org/: accessed 20 Dec. 2007.

Jacquin NJ. 1787. Collectanea 1: 124. Ex Officina Wappleriana, Vindobonae [Wien]

Jacquin NJ. 1788. Collectanea 2: 367. Ex Officina Wappleriana, Vindobonae [Wien].

Jacquin NJ. 1791. Collectanea 4: 216. Ex Officina Wappleriana, Vindobonae [Wien].

Jacquin NJ. 1798. Plantarum rariorum horti caesarei Schoenbrunnensis descriptiones et icones. Opera et sumptibus Nicolai Josephi Jacquin II. Johnson RW. 2004. Stictocardia Hallier f. (Convolvulaceae) in Queensland. Austrobaileya 6, 4: 631-637.

Kalkman C. 1955. A plant-geographical analysis of the Lesser Sunda islands. Acta Botanica Neerlandica 4: 216.

Ker Gawler JB. 1817. Botanical Register 3: t. 239.

Ker Gawler JB. 1818. Botanical Register 4: t. 270.

Kuntze CEO. 1891. Revisio Generum Plantarum II. Felix [etc.], Leipzig. 
Lamarck JBAP. 1792. Encyclopédie méthodique 3 (II): 464, 465, 467, 542. Botanique. Panckoucke, Paris and Plomteux, Liège.

Liao G-I, Chen M-Y, Kuoh C-S. 2005. Pollen morphology of Cuscuta (Convolvulaceae) in Taiwan. Botanical Bulletin of Academia Sinica 46: 75-81.

Lindley J. 1826. In: Edwards, Botanical Register 13. Ridgway, London

Linnaeus C. 1753. Species plantarum. Impensis Laurentii Salvii, Holmiae.

Linnaeus C. 1759. Systema naturae. Editio decima 2: 825-1384. Impensis direct. Laurentii Salvii, Holmiae [Stockholm]

Linnaeus C. 1762. Species plantarum. Editio secunda. 2 vols. Impensis Laurentii Salvii, Holmiae.

Linnaeus C. 1781. Supplementum plantarum Systematis vegetabilium editionis decimae tertiae, Generum plantarum editionis sextae, et Specierum plantarum editionis secunda: 135 .

Mabberley DJ. 1980. Generic names published in Salisbury's reviews of Robert Brown's works. Taxon 29: 597-606.

Magro AJ. 1943. Timor: um pouco da sua história e aspectos actuais da sua vida. Boletim da Sociedade de Geografia de Lisboa 61: 1-2.

Malm J. 1934. Die Phanerogamenflora der Kleinen Sunda-Inseln und ihre Beziehungen. Repertorium Specierum Novarum Regni Vegetabilis 34: 255-307.

Mathée G, Wright AD, König GM. 1999. HIV reverse transcriptase inhibitors of natural origin. PI. Med. (Stuttgard) 65: 493-506.

Miquel FAW. 1856. Flora van Nederlandsch Indie 2: 589. Van der Post, Amsterdam.

Miquel FAW. 1861. Flora van Nederlandsch Indie, Eerste Bijvoegsel 3: 560. Van der Post, Amsterdam.

Monk K, Fretes Y, Reksodiharjo-Lilley G. 1997. The ecology of Nusa Tenggara and Maluku. Periplus Editions Ltd, Hong Kong.

Nicolson DH, Suresh CR, Manilal KS. 1988. An interpretation of Van Rheede's Hortus Malabaricus. Regnum Vegetabile 119: 1-378.

Oliver D. 1883. In: Hooker's Icones Plantarum; or figures, with brief descriptive characters and remarks of new or rare plants 15. Brown, Green \& Longman, London.

Persoon CH. 1805. Synopsis Plantarum. Cramerum, Parisiis Lutetiorum.

Poiret JLM. 1814. Encyclopédie méthodique. Botanique, Suppl. 3, 2: 460, 464, 467, 469. Panckoucke, Paris and Plomteux, Liège.

Robinson BL. 1916. Noteworthy Spermatophytes. Proceedings of the American Academy of Arts and Sciences 51: 530.

Roemer JJ, Schultes J. 1819. Systema vegetabilium 4: 238-254. Cottae, Stuttgardtiae.

Roth AW. 1787. Botanische Abhandlungen und Beobachtungen. Winterschimdt, Nürnberg.

Roth AW. 1797. Catalecta Botanica 1: 36. Bibliopolo Mülleriano, Lipsiae [Leipzig].

Roth AW. 1821. Novae Plantarum Species. Vogleri, Halberstadii.

Roxburgh W. 1799. Plants of the Coast of Coromandel 2, 1: 3, t. 104. Bulmer \& Co. for Nicol, Bookseller, London.

Roxburgh W. 1802. Plants of the Coast of Coromandel 2, 3: 31, t. 159. Bulmer \& Co. for Nicol, Bookseller, London.

Roxburgh W. 1824. Flora Indica 1: 466. Mission Press, Serampore.

Silva JCM. 1910. A mão d'obra em Timor. A Editora, Lisboa.

Silva Manso ALP. 1836. Enumeração das substancias Brazileiras 16: 49. Typographia nacinalii, Rio de Janeiro.

Silveira P, Schuiteman A, Vermeulen JJ, Sousa AJ, Silva H, Paiva J, De Vogel E. 2008. The Orchids of Timor: checklist and conservation status. Botanical Journal of the Linnean Society 157: 197-215.
Spanoghe JB. 1835. Catalogue of the plants found on Timor and neighbouring islands. Companion to the Botanical Magazine 1: 348.

Spanoghe JB. 1841. Prodromus Florae Timorensis. Linnaea 15: 338-341.

Staples GW. 2006. Revision of Asiatic Poranae (Convolvulaceae) - Cordisepalum, Dinetus, Duperreya, Porana, Poranopsis, and Tridynamia. Blumea 51: 403-491.

Staples GW. 2007. Checklist of Pacific Operculina (Convolvulaceae), including a new species. Pacific Science 61: 587-593.

Staples GW, Austin D. 1981. Changes in the West Indian Operculina (Convolvulaceae). Brittonia 33, 4: 591-596.

Staples G, Jarvis CE. 2006. Typification of Linnaean plant names in Convolvulaceae. Taxon 55: 1019-1024.

Stefanovic S, Austin DF, Olmstead RG. 2003. Classification of Convolvulaceae: a phylogenetic approach. Systematic Botany 28, 4: 791-806.

Steudel EG. 1840. hereNomenclator Botanicus Cottae, Stuttgartiae \& Tubingae.

Sweet R. 1825. The British Flower Garden 2. Ridgway \& Sons, London.

Sweet R. 1826. Hortus Britannicus. Ed. 1. 2: 289. Ridgway \& Sons, London.

Sweet R. 1827. Hortus Britannicus. Ed. 1. Reissue. Ridgway, London.

Sweet R. 1830. Hortus Britannicus. Ed. 2. Ridgway, London.

Vahl M. 1791. Symbolae Botanicae 2: 32. Impensis auctoris, Excudebant Nicolaus Möller et filius, Aulae regiae Typographi, Hauniae.

Vahl M. 1794. Symbolae Botanicae 3: 29. Impensis auctoris. Excudebant Nicolaus Möller et filius, Aulae regiae Typographi, Hauniae.

Van Ooststroom SJ. 1934. A monograph of the genus Evolvulus. Mededeelingen van het Botanisch Museum en Herbarium van de Rijks Universiteit te Utrecht 14: 1-267.

Van Ooststroom SJ. 1939. The Convolvulaceae of Malaysia II. Blumea 3: $276-366$.

Van Ooststroom SJ. 1940. The Convolvulaceae of Malaysia III. Blumea 3: 503-574.

Van Ooststroom SJ. 1943. The Convolvulaceae of Malaysia IV. Blumea 5: $348-361$.

Van Ooststroom SJ. 1958. Convolvulaceae. Flora Malesiana, Ser. I, 5, 4: 558-564. Nordhoff-Kolff N.V., Djakarta.

Van Ooststroom SJ. 1972. Convolvulaceae. Flora Malesiana, Ser. I, 6, 6: 936-941. Wolters-Nordhoff Publ., Groningen.

Van Ooststroom SJ, Hoogland RD. 1953. Convolvulaceae. Flora Malesiana, Ser. I, 4, 4: 388-512. Nordhoff-Kolff N.V., Djakarta.

Van Steenis CGGJ. 1950. Flora Malesiana, Ser. I, 1. Malaysian plant collectors and collections. Nordhoff-Kolff N.V., Djakarta.

Verdcourt B. 1987. Three corrections to the Flora of Tropical East Africa. Kew Bulletin 42: 658.

Warburg O. 1894. Botanische Jahrbücher für Systematik, Pflanzengeschichte und Pflanzengeographie 18: 207.

Watt G. 1890. Dictionary of the economic products of India IV: 488.

Wight R, Arnott G. 1837. Clavis analytica of the Convolvulaceae of the Peninsula of India. Madras Journal of Literature and Science 5: 22.

Wright A. 2001. East Timor (Timor Timur) sandalwood plantation development: a feasibility study. Sandalwood Research Newsletter 12: 5-6.

Yuncker TG. 1932. The genus Cuscuta. Memoirs of the Torrey Botanical Club 18: 138.

Zollinger H. 1854. Systematisches Verzeichniss 2: 128-132. Kiesling, Zurich.

\section{IDENTIFICATION LIST}

The numbers between parenthesis after the collector numbers refer to the numerical order used in the taxonomic treatment. The first digit corresponds to the genus number, the following digit(s) to the species number within the genus and the last digit (a, b or $c)$ to the infraspecific name number. A ? means that identification to the species level was not possible. The letter $(T)$ indicates a type specimen.

e.g.: 1.1 = Argyreia paivae; $6.1 \mathrm{~b}=$ Evolvulus alsinoides var. decumbens

Note: Flora Malesiana's Cyclopedia of Collectors (Van Steenis 1950) has been followed whenever the collectors were cited in this compilation. For those names that could not be found in this Cyclopedia of Collectors, surname and initials where included. Exception was made for Silva and José Gomes da Silva, where the opposite was applied, because no initials were available for the specimen collected by the first, and only Silva was used for the second in the mentioned compilation.

Bloembergen $3435(8.1 \mathrm{a})$.

R. Cinatti 29 (8.18); 107 (8.17); 131 (8.24); 165 (11.2); 168 (8.20); 171 (8.13); 194 (13.1); 243 (8.7); 273 (10.4); 295 (10.7); 332 (10.4); 339 (2.1); 366 (6.1a); 369 (9.1a).

Flood s.n. (8.15) - Forbes 3754 (15.1); 3773 (8.2); 3776 (8.13); 3871 (8.20); 4004 (8.14); 4104 (4.1); 4105 (8.13); 4108 (8.13) - C. Friedberg 49 (8.4); 67 (8.4); 144[0?] (14.2); 257a (T) (1.1); 412 (8.13).

Gaudichaud-Beaupré 139 (7.1).

Jaag 75 (8.20); 89 (15.1) - Jonker 273 (1.3); 285 (T) (9.2b); 290 (14.2).
C.W. Kooy 71 (9.1a); 85 (8.24); 10[8] (8.11); 110 (11.2); 152 (6.1b); 241 (7.1); 242 (8.14); 244 (8.23); 249 (8.23); 257 (8.7); 260 (11.2); 263 (11.2); 276 (8.18); 277 (10.7); 283 (8.?); 292 (14.1); 293 (8.1a); 295 (10.5); 362 (3.2); 378 (8.16); 398 (8.11); 455 (6.1a); 481 (11.2); 523 (1.2); 642 (8.1a); 706 (1.1); 727 (3.2); 734 (13.1); 738 (10.2); 793 (8.1a); 794 (10.1); 884 (13.1); 896 (10.5); 903 (3.3); 905 (1.1); 936 (8.8); 981 (10.7); 982 (10.6a); 1252 (8.22); 1294 (9.1a); 1295 (9.1a); 1310 (8.16); 1318 (13.1); 1320 (10.2); 1330 (8.22); 1337 (13.1); 1395 (14.3).

J. Paiva \& P. Silveira 2 (8.3); 9 (8.16); 19a (3.1) - J. Paiva, P. Silveira \& A.J. Sousa 260 (8.24); 261 (8.17); 505 (8.16). 
Reinwardt 36 (8.5); 12(?) (1.2); 1300 (15.1); 1332 (8.5); 1350 (T) (14.1); $1351(\mathrm{~T})(1.2)$.

Sauveur 76 (8.22); 117 (14.3); 121 (10.7) - Schmutz 2294 (14.2); 2365 (13.1) - Silva 6 S (8.16) - Spanoghe 29 (6.1b); 30 (6.1b); 32 (6.1b); 33 (6.1a); 43 (T) (5.1); 54 (8.14); 72 (8.18); 89 (8.11); 91 (10.7); 206 (8.9).

Teysmann 441 (13.1)

Van Steenis 17985 (8.11); 18107 (10.3); 18124 (12.1); 18125 (8.6); 18132 (8.11); 18216 (15.1) - Verdial 14 V. (8.14); 15 (7.1); 21 V. (11.2); 26 V. (8.?); $74(10.7)$ - Voogd 1758 (4.1) - Vriese s.n. (8.18).
Wallich s.n. (10.6) - Walsh-Held 11 (8.14); 48 (6.1a); 65 (8.13); 107 (14.2); 117 (9.1a); 126 (8.11); 153 (1.2); 250 (8.1a); 266 (8.15); 303 (13.1); 310 (8.16); 319 (4.1); 364 (8.16); 373 (T) (14.2); 375 (T) (10.1); 376 (9.1a); 388 (T) (1.3); 389 (7.1); 399 (8.23); 414 (11.2); 422 (8.10); 430 (8.25); 441 (13.1); 478 (10.7).

Zeye s.n. (9.1a) - Zippelius 26 (5.1); 43 (5.1); 45/46 (11.1); 73 (8.18); 91 (T) (13.1); 168 (8.18); 191 A (9.1b); 192 (9.1b); 196 (10.2); 198 (14.2); 199 (10.6a).

\section{INDEX TO NAMES}

Accepted names are in roman type, new species in bold, and synonyms, doubtful [dbt] and insufficiently known [insuf] in italics.

Argyreia Lour. [p. 50]

capitata (Vahl) Choisy [dbt - p. 52]

capitiformis (Poir.) Ooststr. [dbt - p. 52]

guichenotii Choisy 1.2

paivae A.R.Simões \& P. Silveira 1.1

reinwardtiana (Blume) Miq. 1.2

setosa Choisy [dbt - p. 52]

walshae Ooststr. 1.3

Calonyction capillatum Miq. 8.22

mollissimum Zoll. 8.1a

muticum Decne. 8.25

speciosum Choisy 8.2

Convolvulus alsinoides L. 6.1a

batatas L. 8.4

biflorus L. 8.5

brasiliensis L. $8.15 a$

cairicus L. 8.6

gemellus Burm.f. 10.3

hastatus Desr. 15.1

malabaricus L. 7.1

marginatus Desr. 8.20

nil L. 8.12

obscurus L. 8.13

ochraceus Lindl. 8.14

parviflorus Vahl 9.1a

var. tomentosus Warb. 9.1b

pes-caprae L. 8.15

purpureus L. 8.18

scandens Delile 7.1

sublobatus L.f. 7.1

tiliifolius Desr. 14.3

tridentatus L. 15.1

turpethum L. 11.2

umbellatus L. 10.6

vitifolius Burm.f. 10.7

zollingeri Choisy 9.2

Cressa L. [p. 52]

australis R.Br. 2.1

cretica auct. non 2.1

Cuscuta L. [p. 53]

campestris Yunck. 3.1

cassytoides Nees ex Engelm. 3.2

monogyna auct. non 3.2

reflexa auct. non 3.2

timorensis Decne. ex Engelm. 3.2

Dinetus Buch.-Ham. ex Sweet [p. 54]

racemosus (Roxb.) Buch.-Ham. ex Sweet 4.1

Erycibe Roxb. [p. 54]

timorensis Hallier f. ex Hoogl. 5.1

Evolvulus L. [p. 55]

alsinoides var. alsinoides (L.) L. 6.1a

var. decumbens (R.Br.) Ooststr. 6.1b

var. javanicus (Blume) Ooststr. 6.1c

decumbens R.Br. $6.1 \mathrm{~b}$

emarginatus Burm.f. 10.2

hederaceus Burm.f. 10.4

javanicus Blume 6.1c

lanceaefolius Span. 6.1b

linifolius L. [dbt - p. 56]

pseudo-incanus Span. 6.1a

pumilus Span. 6.1a
Hewittia Wight \& Arn. [p. 56]

bicolor (Choisy) Wight \& Arn. 7.1

malabarica (L.) Suresh 7.1

scandens (Milne) Mabb. 7.1

sublobata (L.f.) Kuntze 7.1

Ipomoea L. [p. 56]

aculeata Blume 8.1

var. mollissima (Zoll.) Hallier f. ex Ooststr. $8.1 \mathrm{a}$

alba L. 8.2

angulata Lam. 8.10

angustifolia Jacq. 15.1

aquatica Forssk. 8.3

batatas (L.) Lam. 8.4

biflora (L.) Pers. 8.5

bona-nox L. 8.2

cairica (L.) Sweet 8.6

campanulata L. [dbt - p. 62]

capillata Span. 8.22

carnea subsp. fistulosa (Mart. ex Choisy)

D.F.Austin 8.7

chryseides Ker Gawl. 10.4

crassicaulis (Benth.) B.L.Rob. 8.7

cymosa Roem. \& Schult. 10.6

decaisnei Ooststr. 8.8

digitata auct. non 8.11

eriocarpa R.Br. 8.9

filicaulis Blume 15.

fistulosa Mart. ex Choisy 8.7

grandiflora (L.f.) Lam. 14.3

hispida (Vahl) Roem. \& Schult. 8.9

hederacea auct. non 8.12

hederifolia L. 8.10

insuavis Blume 8.13

marginata (Desr.) Verdc. 8.19

maritima (Desr.) R.Br. 8.15

mauritiana Jacq. 8.11

maxima auct. non 8.20

muricata (L.) Jacq. [insuf - p. 63]

nil (L.) Roth 8.12

obscura (L.) Ker Gawl. 8.13

ochracea (Lindl.) G.Don 8.14

ochroleuca Span. 8.14

paniculata $\mathrm{R} . \mathrm{Br}$. 8.11

paniculata Burm.f. 9.1

pes-caprae (L.) R.Br. 8.15

subsp. brasiliensis (L.) Ooststr. 8.15a

pes-tigridis L. 8.16

petaloidea auct. non 11.1

plebeia R.Br. 8.5

polymorpha Roem. \& Schult. 8.17

pulchra Blume 14.3

pumila Span. 8.17

purpurea (L.) Roth 8.18

quamoclit L. 8.19

quinata R.Br. 10.5

reinwardtiana Blume 1.2

reniformis Choisy 10.2

repanda auct. non 8.21

repens Roth 8.3

reptans Poir. 8.3
Ipomoea (cont.)

riedeliana Oliv. 11.1

sagittifolia Burm.f. 8.20

sepiaria J.Koenig ex Roxb. 8.20

setosa Blume 8.12

sumatrana (Miq.) Ooststr. 8.21

trichocalyx Steud. 8.12

trichosperma Blume 8.22

trichotosa Blume [dbt - p. 52]

tricolor Cav. 8.23

triloba L. 8.24

tuba (Schltdl.) G.Don 8.25

turpethum (L.) R.Br. 11.2

verrucosa Blume 8.20

violacea L. 8.25

vitifolia (Burm.f.) Sweet 10.7

Jacquemontia Choisy [p. 63]

paniculata (Burm.f.) Hallier f. 9.1

var. paniculata 9.1a

var. tomentosa (Warb.) Ooststr. 9.1b

zollingeri (Choisy) Hallier f. 9.2

var. jonkeri Ooststr. 9.2b

var. zollingeri $9.2 a$

Lepistemon reniformis (Roxb.) Hassk. 10.2

Lettsomia sumatrana Miq. 8.21

Merremia Dennst. ex Endl. [p. 64]

dichotoma Ooststr. 10.1

emarginata (Burm.f.) Hallier f. 10.2

gemella (Burm.f.) Hallier f. 10.3

hederacea (Burm.f.) Hallier f. 10.4

quinata (R.Br.) Ooststr. 10.5

tridentata (L.) Hallier f. 15.1 subsp. angustifolia (Jacq.) Ooststr. 15.1 subsp. hastata (Desr.) Ooststr. 15.1 umbellata (L.) Hallier f. 10.6

subsp. orientalis (Hallier f.) Ooststr. 10.6a var. orientalis Hallier f. 10.6a vitifolia (Burm.f.) Hallier f. 10.7

Operculina Silva Manso [p. 66]

riedeliana (Oliv.) Ooststr. 11.1

turpethum (L.) Silva Manso 11.2

Pharbitis nil (L.) Choisy 8.12

variifolia Decne. 8.8

Polymeria R.Br. [p. 67]

pusilla R.Br. 12.1

Porana Burm.f. [p. 67]

racemosa Roxb. 4.1

volubilis Burm.f. 13.1

var. burmanniana Blume 13.1

var. microcarpa Engl. 13.1

Quamoclit vulgaris Choisy 8.19

Shutereia bicolor Choisy 7.1

Stictocardia Hallier f. [p. 67]

discolor Ooststr. 14.1

neglecta Ooststr. 14.2

tiliifolia (Desr.) Hallier f. 14.3

Xenostegia D.F.Austin \& Staples [p. 68]

tridentata (L.) D.F.Austin \& Staples 15.1 